\title{
Greenhouse gas mitigation in Chinese agriculture: distinguishing technical and economic potentials
}

\author{
Wen Wang ${ }^{1,2}$, Frank Koslowski ${ }^{3}$, Dali Rani Nayak ${ }^{4}$, Pete Smith ${ }^{4}$, Eli \\ Saetnan ${ }^{5}$, Xiaotang Ju ${ }^{6}$, Liping Guo ${ }^{1}$, Guodong Han $^{7}$, Christian de \\ Perthuis ${ }^{2}$, Erda Lin ${ }^{1}$ and Dominic Moran ${ }^{3}$
}

China is now the world's biggest emitter of greenhouse gases with 7467 million tons (Mt) carbon dioxide equivalent $\left(\mathrm{CO}_{2} \mathrm{e}\right)$ in 2005 , with agriculture accounting for $11 \%$ of this total. As elsewhere, agricultural emissions mitigation policy in China faces a range of challenges due to the biophysical complexity, the heterogeneity of farming systems, and social-economic barriers. Existing research has contributed to improving our understanding of the technical potential of mitigation measures in this sector (i.e. what works). But for policy purposes it is important to convert these measures into a feasible economic potential, which provides a perspective on whether agricultural emissions reduction measures are low cost relative to mitigation measures and overall potential offered by other sectors of the economy. We develop a bottom-up marginal abatement cost curve (MACC) representing the cost of mitigation measures applicable in addition to business-as-usual agricultural practices. The MACC demonstrates that while the sector can offer a maximum technical mitigation potential of $402 \mathrm{MtCO} e$ in 2020, of which a reduction of $135 \mathrm{MtCO} e$ is potentially available at zero or negative cost (i.e. a cost saving), and $176 \mathrm{MtCO}$ e (approximately $44 \%$ of the total) can be abated at a cost below a threshold carbon price of $¥ 100$ (approximately $€ 12$ ) per tCO2e. Our findings highlight cost-effectiveness of nitrogen fertilizer and manure best management practices, and animal breeding practices. We outline the assumptions underlying MACC construction and discuss some scientific, socioeconomic and institutional barriers to realizing the indicated levels of mitigation.

Keywords: China, agriculture, climate change, greenhouse gas mitigation, marginal abatement cost curve (MACC)

1. Institute of Environment and Sustainable Development in Agriculture, Chinese Academy of Agricultural Sciences, Beijing 100081, China

2. Climate Economics Chair, Paris-Dauphine University, Paris 75002, France

3. Land Economy and Environment Research Group, Scotland's Rural College, Edinburgh EH9 3JG, Scotland

4. University of Aberdeen, Aberdeen AB24 3UU, Scotland

5. Aberystwyth University, Aberystwyth SY23 3FL, UK

6. College of Resources and Environmental Sciences, China Agricultural University, Beijing 100193, China

7. College of Ecology and Environmental Science, Inner Mongolia Agricultural University, Hohhot 010018, Inner Mongolia, China

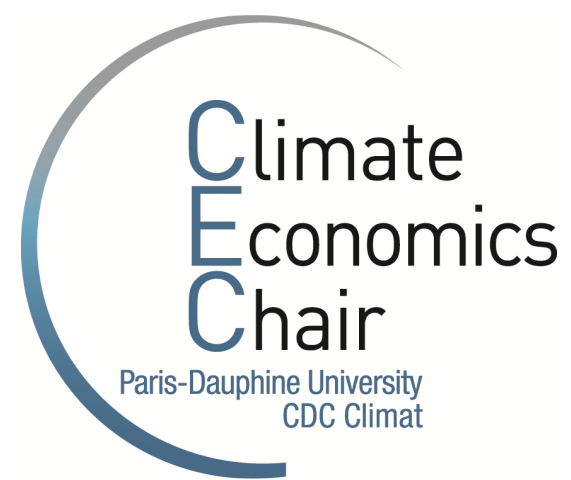





\section{Title}

Greenhouse gas mitigation in Chinese agriculture: distinguishing technical and economic potentials

\section{Author names and affiliations}

Wen Wang ${ }^{\mathrm{a}, \mathrm{b}}$, Frank Koslowski ${ }^{\mathrm{c}}$, Dali Rani Nayak ${ }^{\mathrm{d}}$, Pete Smith ${ }^{\mathrm{d}}$, Eli Saetnan ${ }^{\mathrm{e}}$, Xiaotang Ju ${ }^{\mathrm{f}}$, Liping Guo $^{\mathrm{a}}$, Guodong Han ${ }^{\mathrm{g}}$, Christian de Perthuis ${ }^{\mathrm{b}}$, Erda Lin ${ }^{\mathrm{a},{ }^{*}}$, Dominic Moran ${ }^{\mathrm{c}}$

${ }^{a}$ Institute of Environment and Sustainable Development in Agriculture, Chinese Academy of Agricultural Sciences, Beijing 100081, China, ${ }^{\mathrm{b}}$ Climate Economics Chair, Paris-Dauphine University, Paris 75002, France, ${ }^{\mathrm{c}}$ Land Economy and Environment Research Group, Scotland's Rural College, Edinburgh EH9 3JG, Scotland, ${ }^{\text {d } U n i v e r s i t y ~ o f ~ A b e r d e e n, ~ A b e r d e e n ~ A B 24 ~ 3 U U, ~ S c o t l a n d, ~}$ ${ }^{\mathrm{e}}$ Aberystwyth University, Aberystwyth SY23 3FL, UK, ${ }^{\mathrm{f}}$ College of Resources and Environmental Sciences, China Agricultural University, Beijing 100193, China, ${ }^{\mathrm{g}}$ College of Ecology and Environmental Science, Inner Mongolia Agricultural University, Hohhot 010018, Inner Mongolia, China

Wang W. and Koslowski F. contributed equally to this work.

*Corresponding author: Erda Lin, tel. +86 10 82105998, fax +86 10 82105998, e-mail: lined@ami.ac.cn; address: Room 303, Institute of Environment and Sustainable Development in Agriculture, Chinese Academy of Agricultural Sciences, Beijing 100081, China

\section{Acknowledgements}

This study is supported by the project "Integration and demonstration of key carbon sequestration and mitigation technologies in the agricultural ecosystems" funded by the Chinese Ministry of Science and Technology (2013BAD11B00) and the UK-China Sustainable Agriculture Innovation Network projects. We thank Prof. Weifeng Zhang at the China Agricultural University and Prof. Xiaoyuan Yan at the Institute of Soil Science Nanjing of Chinese Academy of Sciences for providing valuable insights to cropland mitigation potential, Dr. Yan Jun (Center for Chinese Agricultural Policy of Chinese Academy of Sciences) for providing CAPSiM model results, and Valentin Bellassen at CDC Climat for critical review and comments. Dominic Moran acknowledges funding from Scottish Government Rural and Environmental Science and Analytical Services division through ClimatexChange (http://www.climatexchange.org.uk/). 


\begin{abstract}
:
China is now the world's biggest emitter of greenhouse gases with 7467 million tons (Mt) carbon dioxide equivalent $\left(\mathrm{CO}_{2} \mathrm{e}\right)$ in 2005 , with agriculture accounting for $11 \%$ of this total. As elsewhere, agricultural emissions mitigation policy in China faces a range of challenges due to the biophysical complexity, the heterogeneity of farming systems, and social-economic barriers. Existing research has contributed to improving our understanding of the technical potential of mitigation measures in this sector (i.e. what works). But for policy purposes it is important to convert these measures into a feasible economic potential, which provides a perspective on whether agricultural emissions reduction measures are low cost relative to mitigation measures and overall potential offered by other sectors of the economy. We develop a bottom-up marginal abatement cost curve (MACC) representing the cost of mitigation measures applicable in addition to business-as-usual agricultural practices. The MACC demonstrates that while the sector can offer a maximum technical mitigation potential of $402 \mathrm{MtCO}_{2} \mathrm{e}$ in 2020, of which a reduction of $135 \mathrm{MtCO}_{2} \mathrm{e}$ is potentially available at zero or negative cost (i.e. a cost saving), and $176 \mathrm{MtCO}_{2} \mathrm{e}$ (approximately $44 \%$ of the total) can be abated at a cost below a threshold carbon price of $¥ 100$ (approximately $€ 12$ ) per $\mathrm{tCO}_{2} \mathrm{e}$. Our findings highlight cost-effectiveness of nitrogen fertilizer and manure best management practices, and animal breeding practices. We outline the assumptions underlying MACC construction and discuss some scientific, socioeconomic and institutional barriers to realizing the indicated levels of mitigation.
\end{abstract}

Keywords: China, agriculture, climate change, greenhouse gas mitigation, marginal abatement cost curve (MACC)

\title{
Research highlights
}

- Marginal abatement costs of greenhouse gas mitigation from Chinese agriculture are assessed.

- Technically feasible to cut emissions by about $1 / 3$ in 2020 against baseline emissions.

- Significant potential for win-win abatement, avoiding emissions while providing financial savings.

- Analysis highlight the mitigation potential of improved $\mathrm{N}$ fertilizer and manure management practices and breeding practices.

- Institutional and behavioral barriers warrant further analysis to facilitate mitigation policy 


\section{Introduction}

Greenhouse gas (GHG) emissions in China reached 7467 million tons (Mt) carbon dioxide equivalent $\left(\mathrm{CO}_{2} \mathrm{e}\right)$ in 2005 excluding land use, land use change and forestry (NCCC, 2012), and agriculture accounted for $11 \%$ of this total, or approximately $820 \mathrm{MtCO}_{2} \mathrm{e}$. Agriculture is responsible for over $70 \%$ of national nitrous oxide $\left(\mathrm{N}_{2} \mathrm{O}\right)$ emissions and approximately $50 \%$ of methane $\left(\mathrm{CH}_{4}\right)$ emissions, arising mainly from the use of synthetic nitrogen $(\mathrm{N})$ fertilizers, livestock enteric fermentation, rice cultivation and animal waste management. Between 1994 and 2005, emissions from livestock enteric fermentation (37\% of 2005 total agriculture emissions) surpassed cropland (25\% of the total) as the largest agricultural source of GHG emissions (only including $\mathrm{N}_{2} \mathrm{O}$ and $\left.\mathrm{CH}_{4}\right)(\mathrm{NCCC}$, 2004, 2012). Rice cultivation $\left(\mathrm{CH}_{4}\right)$ and livestock waste management $\left(\mathrm{N}_{2} \mathrm{O}\right.$ and $\left.\mathrm{CH}_{4}\right)$ contributed around $20 \%$ and $18 \%$, respectively (NCCC, 2012).

In China, national policy aspirations for agricultural mitigation have traditionally been eclipsed by food security ambitions, with any convergence of production and climate objectives focusing mainly on increasing productivity. But ambitious national mitigation aspirations have recently been outlined in the $12^{\text {th }}$ Five-Year Plan (FYP), which targets a $17 \%$ reduction in carbon intensity (emissions) per unit of Gross Domestic Product. In response, the Ministry of Agriculture (MOA) has initiated programs to mitigate agricultural emissions by improving agricultural productivity by 2015 . These include a $3 \%$ improvement in fertilizer use efficiency, enhancing irrigation water use efficiency by $6 \%$, accelerating the development of household biodigesters, and improving degraded grasslands. The $12^{\text {th }}$ FYP Plan also accommodates a significant increase $(+0.45 \%$ per year $)$ in scientific research funding.

Existing global reviews (e.g. Oenema et al., 2001; IPCC, 2007; Smith et al., 2008, 2013) suggest that agriculture offers significant technical potential to mitigate climate change through both emissions reduction and carbon sequestration in terrestrial ecosystems. Technically feasible GHG measures identified as applicable in both arable and livestock systems can be broadly grouped into increased $\mathrm{N}$-use efficiency, reduced $\mathrm{CH}_{4}$ emissions from livestock rumen and rice paddy, sequestering $\mathrm{C}$ into cultivated and grassland soils, and energy efficiency to reduce $\mathrm{CO}_{2}$ emissions. Some reviews (e.g. Wreford et al., 2010) indicate that many mitigation measures can be implemented immediately using current technologies, simultaneously reducing input costs or improving productivity. Beyond such initial win-wins, some agricultural abatement options also afford co-benefits with regards to water quality, biodiversity conservation, food security, rural development and poverty alleviation, all of which have high importance in rural China.

Existing research in China has examined and quantified technical abatement potentials for specific agriculture mitigation measures (Lin et al., 2005; Lu et al., 2009; Huang and Tang, 2010; Nayak et al., 2013a, 2013b; Saetnan et al., 2013). These studies provide some insights into how mitigation potentials can be applied across the range of biophysical conditions that characterize Chinese farming systems. Beyond the farm gate, further insights have been provided by life-cycle analysis targeting the $\mathrm{N}$ 
fertilizer production and consumption chain (Zhang et al., 2013). But to date there is no synthesis estimate of overall technically feasible mitigation potential in agriculture, nor any estimate of the cost-effectiveness (CE) of abatement measures in China. Such research would consider the relative abatement cost of implementing each measure and would provide information on how agricultural abatement costs compare with both a benchmark carbon price and abatement elsewhere in the economy. This is significant, since in allocating an emissions budget to a sector, a rational mitigation policy should normally prioritize the cheapest means of abatement first and equalize marginal abatement costs across sectors. Such information is also crucial, for instance, for developing any market-based approach based on offering low cost mitigation credits to any emerging carbon market. While agriculture has been slow to graduate to such market schemes, the inception of emissions trading regimes in China is likely to lead to an increasing scrutiny of the relative cost of emissions reductions in all sectors of the economy.

This paper considers the extent of biophysical data on agricultural mitigation measures and outlines the stages in moving from a technical potential to an estimate of feasible economic mitigation potential. The methodological approach involves the use of a bottom-up or engineering marginal abatement cost curve (MACC), which allows the aggregation of the mitigation potential arising from the application of a subset of cost-effective measures above a notional baseline level of activity that we denote as business as usual (BAU). This analysis considers measures applicable within the farm gate and the direct cost and benefit implications for farmers life-cycle impacts of the measures and energy use related emissions are not within the scope of this MACC exercise. The paper covers the sections of MACC construction, presentation of key results and a discussion of data. It also reflects on the behavioral and institutional barriers to the realization of estimated mitigation potentials. 


\section{MACC construction}

Technically feasible mitigation measures will normally be differentiated in terms of their implementation cost to farmers and their wider net environmental impacts borne by society. An economic mitigation potential considers the cost of applying the measures as well as their likely adoption rate relative to a baseline of no additional mitigation activity (BAU scenario), which may be limited by institutional and farm-scale (including behavioural) barriers.

In the first instance it is useful to rank abatement measures in order of decreasing CE; i.e. the implicit cost of each ton ( $\mathrm{t}$ ) of $\mathrm{CO}_{2} \mathrm{e}$ mitigated were each measure fully implemented, and then to estimate the annual cumulative potential over a target time horizon offered by all cost-effective measures applied above baseline activity. MACCs offer a rational framework for combining biophysical and economic data to reflect mitigation costs. In this application we adopt the bottom-up or engineering approach to MACC construction that has been used in several previous studies (Beach et al., 2008; Moran et al., 2011; Schulte et al., 2012; Pellerin et al., 2013).

On the right hand side of Fig. 1, each bar represents a feasible abatement measure, differentiated by implementation cost per ton of $\mathrm{CO}_{2} \mathrm{e}$ emission reduced (height of bar), and quantity of emissions they can mitigate if the measure is fully applied to its technical potential (width of bar). Measures below the $\mathrm{x}$-axis are cost negative, i.e. removing emissions and saving society costs, those above incur positive cost. Therefore, the biggest financial gains and emission reductions can be seen in the longest and widest bars beneath $\mathrm{x}$-axis, and conversely bars above the $\mathrm{x}$-axis are the costlier measures. Policy therefore needs to focus first on the implementation of the former. An economic potential can be derived by selecting those measures that fall below a cost threshold set by a notional benchmark carbon price (horizontal dashed line). This threshold can be established with reference to traded or non-traded carbon prices and can rule out higher cost measures, and thereby define an economic potential that is less than the full technical potential.

Bottom-up MACCs are best-suited to explore and reflect the complexity and diversity of Chinese agricultural systems, specifically heterogeneity in terms of abatement potential, measure applicability and implementation costs. Overall, the aim is to derive the $\mathrm{CE}$ of each individual measure implemented in Chinese average conditions.

The basic steps for bottom-up MACC derivation followed the methodology by Moran et al. (2011):

1. Develop BAU or baseline emissions scenario for the target year 2020.

2. Screen mitigation measures technically applicable in Chinese agriculture.

3. Quantify the abatement rate of selected measures in terms of $\mathrm{tCO}_{2} \mathrm{e}$ abated per hectare or per animal head, based on relevant studies or existing meta-analysis results.

4. Estimate implementation costs/benefits of mitigation measures for farmers as $¥$ per hectare $\left(\mathrm{ha}^{-1}\right)$ or $¥$ animal $^{-1}$ in 2020 prices accounting for anticipated future price rise in various 
agricultural inputs. Calculate the net present value (NPV) using a discount rate and express CE in terms of $¥ \mathrm{tCO}_{2} \mathrm{e}^{-1}$ in the chosen benchmark year (here 2010).

5. Estimate measure uptake under the BAU scenario and maximum feasible adoption in the target year 2020 to deduce overall mitigation potential, taking into account measure interactions.

6. Draw the MACC, showing the relationship between abatement potential and cost.

\subsection{Projecting BAU emissions from Chinese agriculture in 2020}

Since there is no robust projection of GHG emissions from Chinese agriculture, we followed the IPCC 2006 guideline (IPCC, 2006) to compile a baseline emission inventory to 2020. We considered both direct and indirect $\mathrm{N}_{2} \mathrm{O}$ emissions from the three major $\mathrm{N}$ input sources: synthetic fertilizers, organic manure and crop residues, plus $\mathrm{CH}_{4}$ emissions from enteric fermentation, manure management and rice paddies.

Historical agriculture activity data (cropping area, production, yield, livestock numbers, selling price) were extracted from the China Rural Statistical Yearbooks (MOA, 2001-2012a) and the China Livestock Yearbooks (MOA, 2001-2012b). Future activity data for 2012 to 2020 were drawn from model projections using CAPSiM, which analyzes the impacts of policy changes and other external factors on China's agricultural production, consumption, prices and trade (Huang and Li, 2003). Model output was provided by the Center for Chinese Agricultural Policy of the Chinese Academy of Sciences (Table A.1, Table A.2). A forecast of total agricultural use of synthetic $\mathrm{N}$ fertilizers was based on IFADATA (IFA, 2013), assuming a 1\% annual growth rate (Zhang et al., 2013) from 2012 to 2020 (Table A.3). Per hectare $\mathrm{N}$ application rates for different crops were collected from the China Agricultural Products Cost-Benefit Yearbooks (NDRC, 1998-2013), with linear extrapolation used to predict future trends (Table A.3). China-specific emission factors for direct and indirect $\mathrm{N}_{2} \mathrm{O}$ emissions from cropland and manure were obtained from studies by Gao et al. (2011), Zhang et al. (2013) (Table B.1) and Wang et al. (2010). The CH4MOD model provided predicted $\mathrm{CH}_{4}$ emissions from rice paddies; data originally compiled for the National GHG Emission Inventories (Zhang et al., 2011), and adjusted for rice cropping area in 2020. Estimated total manure production was based on regionalized manure excreta production per species derived by Wang et al. (2006), and share of liquid and solid manure reported by Hang et al. (2012). We estimated the rumen $\mathrm{CH}_{4}$ production as well as $\mathrm{CH}_{4}$ production from manure based on local Chinese emission factors ( $\mathrm{Fu}$ and $\mathrm{Yu}, 2010$ ).

An attempt to validate these data assumptions revealed a disparity between our GHG emissions estimates from enteric fermentation and manure management, and those produced for the China national inventory (NCCC, 2012). Since assumptions underlying the latter cannot be publically accessed, this study assumed a percentage increase of the baseline emissions from 2005 (stated by the national GHG inventory, NCCC, 2012) until 2020, which was observed in our estimation.

Other information required for baseline emissions compilation was selected from relevant 
literature and IPCC default values (Table B.2 and Table B.3) corresponding to conditions in China (Appendix B).

\subsection{Screening mitigation measures}

Through expert elicitation and literature review, we identified a long list of 32 technical mitigation measures applicable in Chinese conditions. The selection used the following screening criteria: (a) measures likely to reduce yields were excluded to be consistent with the national food security priority; (b) measures with limited applicability at the national level due to technical, political or obvious social barriers, were eliminated, e.g. rice-duck-fish integrated farming systems; (c) measures currently being practiced but increasing GHG emissions were removed, e.g. net emissions from direct straw return to rice paddies tend to be positive; (d) some detailed sub-sector measures were aggregated to account for measure interactions, e.g. water regimes should generally be coupled with fertilizer management practices in rice paddies. Measures selected for analysis are described in Table 1a and 1b.

\subsection{Quantifying abatement rates}

Based on China-specific experimental data, meta-analysis exercises were carried out to derive the annual abatement rates of some mitigation measures (Nayak et al., 2013a, 2013b; Saetnan et al., 2013). These data were further adjusted and to better accommodate additional experimental evidence outside the range of published studies and to partially internalize measure interactions (Appendix C). Abatement rates for different applicable crops/species were quantified to derive the weighted average abatement rates. Since mitigation can be achieved through both enhancing carbon sequestration in croplands/grasslands and reducing $\mathrm{N}_{2} \mathrm{O}$ and $\mathrm{CH}_{4}$ emissions, we evaluated the overall effects on soil organic carbon (SOC) and $\mathrm{N}_{2} \mathrm{O}$ and $\mathrm{CH}_{4}$ emissions from introducing each abatement measure against the baseline.

Table C.1 presents the direct $\mathrm{N}$ rate decrease induced abatement potential of measures $\mathrm{C} 1, \mathrm{C} 2, \mathrm{C} 3$ and $\mathrm{C}$, which were estimated employing emission factors (Table B.1), and the relationship between $\mathrm{N}$ fertilizer reduction and $\mathrm{N}_{2} \mathrm{O}$ emissions reduction (Fig. C.1) drawn from site experiments (database from Nayak et al., 2013a). Abatement potentials of measures C1 and C2 (Table 1a) for rice, wheat and maize were aggregated from provincial level mitigation potentials (Table C.1). Abatement rates of other measures were generally countrywide estimates due to the lack of regional data. The abatement rate of measure $\mathrm{C} 3$ is the integrated effects of shifting from mid-season drainage (F-D-F) to an intermittent irrigation (F-D-F-M) regime and reduced $\mathrm{N}$ fertilizer rate. The abatement rate for $\mathrm{C} 5$ using enhanced efficiency fertilizers were based on global meta-analysis results (Akiyama et al., 2010). Original meta-analysis results of $\mathrm{C} 6$ were discounted because organic manure has already been applied to croplands in practice as opposed to the zero organic manure under controlled experiments. For measures L3-L8 we considered only the dominant ruminant and grazing species (beef cattle, dairy cow, sheep and goats), 
since the application of mitigation measures aiming to reduce rumen $\mathrm{CH}_{4}(\mathrm{~L} 3-\mathrm{L} 5)$ or targeting carbon sequestration in grasslands (L6 - L8) would result in low mitigation potential for other large herbivores and non ruminants (i.e. poultry), and are therefore excluded. Since the dietary measures (L3 - L5) should be applied on a daily basis, we considered only housed animals for their application.

\subsection{Measure implementation costs}

Implementation costs (expressed as $¥ \mathrm{ha}^{-1}$ for cropland and grassland measures and $¥$ animal $^{-1}$ for livestock measures) were estimated by changes in yields, input costs (e.g. fertilizer, pesticide, seeds, feed additives), investment, labor, machinery and irrigation costs, compared to conventional practices where relevant. Costs represent direct costs to farmers in complying with a measure. Indirect and social costs/benefits are excluded from the analysis. The former include costs associated with changes in government subsidies and extension service improvement. Social costs refer to wider environmental impacts of implementing some measures (e.g. reduced water or air pollution).

A literature review and expert consultation were used to identify the on-farm implications and likely costs and benefits of mitigation practices. Typical agricultural inputs and output values for average showcase farms across China were obtained from data in the China Agricultural Products Cost-Benefit Yearbook (NDRC, 1998-2012). Yield effects of integrated nutrient management were drawn from Zhang et al. (2012a), although these were modified in this study since average yields are predicted to be higher in 2020 than in 2010 (Table A.1). Measure implementation also induces changes in agricultural inputs and production costs, which are summarized in Table 2a and 2b (See Table D.1 for detailed cost estimation and data sources). Annual growth rates of agricultural input prices for 2010-2020 are assumed to be half those over the period 2000-2010 (Table D.2) for two reasons. First, average grain sale prices to 2020 are predicted to grow at half the rate of 2000-2010 (Table A.1). Second, agricultural inputs prices are highly dependent on energy prices, which are anticipated to grow by $4-5 \%$ per year beyond 2010 compared with 10.8\% during 2000-2010 (IEA, 2012). Measure lifetime costs were converted to 2010 present values using a social discount rate of $7 \%$.

\subsection{Measure adoption under BAU and abatement scenarios}

Abatement scenarios to 2020 are additional to BAU or baseline activity (Fig. 1). But the actual mitigation extent depends on behavioral, political and market constraints that effect measure uptake. BAU uptake scenarios (Table D.1) were derived with reference to either relevant policy targets or historical trends; those under the abatement scenario were derived from expert judgment, scientific literature, and applicability of the specific measure.

Crop and soil measures $\mathrm{C} 1, \mathrm{C} 2$ and $\mathrm{C} 4$ are assumed to be applicable in provinces and municipalities with lower Nitrogen Partial Factor of Productivity $\left(\mathrm{PFP}_{\mathrm{N}}\right)$ than target levels (Table C.1). 
Changes in water regime patterns in rice paddies (measure C3) referred to results in Zou et al. (2009) and Zhang et al. (2011). Baseline extension areas of high-efficient irrigation systems (C4), conservation tillage (C7) and straw returning (C8) correspond to explicit targets set in the National Agricultural Water-Saving Outline (2012-2020) (State Council, 2012), the National Agriculture Mechanization Extension Plan (2011-2015) (MOA, 2011), and the Implementation Plan on the Comprehensive Use of Crop Straw during the 12th FYP Period (NDRC, 2011a).

Baseline application areas for grazing bans (L6), and reduced grazing intensity (L7 and L8) were based on historical rates of seasonal bans, rotational grazing, and prohibited grazing, stated in the Report on the State of the Environment of China (MOEP 2005 - 2011), and policy targets set out in (MOA, 2006). We assumed that the majority of Chinese grazed grasslands are under heavy grazing pressure. Medium grazing intensity and low grazing intensity refer to grassland utilization rates of 50\% and 35\%, respectively (Patton et al., 2007). BAU application and additional application potential for anaerobic digestion (L1) are based on MOA (2007), NDRC (2007) and Zhang et al. (2012b). The additional application potential of the dietary mitigation measures (L3 - L5) are based on literature review and expert judgment (See a detailed summary on baseline and adoption rates in Table D.3).

\subsection{Measure interactions}

The stand alone abatement rate and CE of one measure may change when applied in combination with others. For crop measures, interactions are addressed by assigning implementation priorities to selected mitigation options. These were determined using expert input. For example, if measure $\mathrm{C} 1$ and $\mathrm{C} 2$ allow $\mathrm{N}$ application rates to decrease from $300 \mathrm{~kg} \mathrm{ha}^{-1}$ to $200 \mathrm{~kg} \mathrm{ha}^{-1}$, the mitigation effect of adding nitrification inhibitors (measure C5) will be based on the $\mathrm{N}$ rate of $200 \mathrm{~kg} \mathrm{ha}^{-1}$. The potential of adding organic manure to rice paddies (measure C6) was quantified under the intermittent water regime (F-D-F-M) realized through measure $\mathrm{C} 3$.

Further adjustments were also made to accommodate potential overlapping application of measures with similar effects (e.g. organic manure and biochar) or subordinating relationships (e.g. conservation tillage and straw returning). Further, the efficacy of increasing organic manure to lands will be discounted when applied jointly with conservation tillage or straw returning, all of which achieve mitigation through carbon sequestration in soils. We therefore assign an interaction factor (0.8) to the stand-alone abatement rates of the three measures on wheat and maize areas. We assume that measure interactions shall not affect the implementation costs of measures.

All three grassland (L6 - L8) and dietary mitigation options (L3 - L5) are mutually exclusive. Lacking more detailed data, we assume that grazing controls or intensities are implemented in approximately $1 / 3$ of the total grazed grassland in China. Applications of multiple feed additives have no additive effect on emissions or productivity. Hence, multiple dietary mitigation options will not be applied simultaneously. To avoid double counting, an equal application of each of the 3 dietary 
mitigation options is assumed; i.e. all livestock receive only one feed additive.

\subsection{MACC derivation}

In the livestock, cropland and grassland sector, the $\mathrm{CE}\left(¥ \mathrm{tCO}_{2} \mathrm{e}^{-1}\right)$ of a measure was calculated by dividing the weighted mean cost $\left(¥ \mathrm{ha}^{-1} \mathrm{yr}^{-1}\right.$ or $¥$ animal $\left.^{-1} \mathrm{yr}^{-1}\right)$ by the average abatement rate $\left(\mathrm{tCO}_{2} \mathrm{e}\right.$ $\mathrm{ha}^{-1} \mathrm{yr}^{-1}$ or $\mathrm{tCO}_{2} \mathrm{e}$ animal ${ }^{-1} \mathrm{yr}^{-1}$ ), and its total mitigation potential volume was computed from per unit abatement rate and additional application area or head of population. Mitigation options were represented by bars on the plot in order of CE on the $\mathrm{x}$-axis and the bar width denotes the annual mitigation potential of the specific measure. Abatement scenarios up to 2020 were drawn assuming measures adopted at a linear rate over time. This assumption initially allows us to side-step a range of potential policy scenarios and instruments incentivizing uptake. 


\section{Results}

\subsection{Baseline agricultural GHG emissions}

Fig. 2 shows that GHG emissions will continue to increase from both crop fields and livestock. Baseline GHG emissions are predicted to reach $1195 \mathrm{MtCO}_{2} \mathrm{e}$ in 2020, a $28.6 \%$ increase from 2010 levels. Cropland GHG emissions are predicted to be $422 \mathrm{Mt} \mathrm{CO}_{2} \mathrm{e}$ in $2020 . \mathrm{N}_{2} \mathrm{O}$ emissions from croplands see significant growth by $18.5 \%$ between 2010 and 2020 driven by increasing synthetic $\mathrm{N}$ fertilizer application. In contrast, a declining trend is observed for $\mathrm{CH}_{4}$ emissions from rice paddies due to improved water regimes. Livestock GHG emissions are $742 \mathrm{Mt} \mathrm{CO}_{2} \mathrm{e}$ in 2020, an increase of 51\% compared to 2005 levels (NCCC, 2012).

The Second National GHG Inventory reported $208 \mathrm{MtCO}_{2} \mathrm{e}$ emissions from cropland $\left(\mathrm{N}_{2} \mathrm{O}\right)$ and $143 \mathrm{MtCO}_{2} \mathrm{e}$ from rice paddies $\left(\mathrm{CH}_{4}\right)$, excluding $\mathrm{CH}_{4}$ emissions from winter-flooded paddy fields in 2005, using 310 and 21 as the Global Warming Potential (GWP) of $\mathrm{N}_{2} \mathrm{O}$ and $\mathrm{CH}_{4}(\mathrm{NCCC}, 2012)$. Our estimates of $188 \mathrm{MtCO}_{2} \mathrm{e} \mathrm{N} 2 \mathrm{O}$ emissions and $164 \mathrm{MtCO}_{2} \mathrm{e} \mathrm{CH}_{4}$ emissions are comparable to these data and differences can be attributed to different GWPs.

\subsection{Mitigation potential and measure CE}

Mitigative effects and stand-alone abatement rate of mitigation measures are summarized in Table 2 and 
Table 4 (a, b). For arable land, average abatement rates range from $0.201 \mathrm{tCO}_{2} \mathrm{e} \mathrm{ha}{ }^{-1}$ from further $\mathrm{N}$ rate reduction in wheat and maize fields, to $1.337 \mathrm{tCO}_{2} \mathrm{e} \mathrm{ha}^{-1}$ delivered by improved fertilization and irrigation regimes in rice paddies. High mitigation benefits can be achieved through best nutrient management practices in cash crop fields where $\mathrm{N}$ overuse and misuse is prevalent (Zhang et al., 2012a). For livestock, tea saponin and lipid addition show abatement rates with reduced rumen $\mathrm{CH}_{4}$ by $15 \%$ per animal (Table 4). The abatement rates for grassland measures are large compared to cropland measures with 1.07, 0.88, and $0.71 \mathrm{t} \mathrm{CO}_{2} \mathrm{e} \mathrm{ha}^{-1}$ for grazing ban, light grazing intensity (LGI) and medium grazing intensity (MGI), respectively (Table 4).

Implementation costs, $\mathrm{CE}$ and overall annual abatement potential of mitigation measures (incorporating measure interactions) for 2020 are also summarized in 
Table 5. The most $\mathrm{CE}$ arable measures with highest mitigation potential are $\mathrm{N}$ fertilizer best management practices, which provide over $40 \%$ of cropland abatement potential. Although more efficient recycling of organic manure to croplands also offers significant potential, substantial commercial manure fertilizer purchase costs or labor requirements for manure composting may prevent its widespread adoption. Implementation of biochar addition would be restricted by high cost at 5478 $¥ \mathrm{tCO}_{2} \mathrm{e}^{-1}$. In contrast, the relatively low potential of conservation tillage can be attributed to significant measure uptake under the BAU scenario due to policy enforcement, leaving limited scope for additional application.

Significant negative cost livestock measures are supplementary feeding of probiotics and tea saponins, breeding measures, and biomass gasification; the latter generating the highest GHG reduction. Medium grazing intensity also accounts for a large abatement potential, available at relative low cost of $64 ¥ \mathrm{tCO}_{2} \mathrm{e}^{-1}$. Despite showing a large GHG reduction potential, supplementary lipid feed supplement is expensive with CE of $1950 ¥ \mathrm{tCO}_{2} \mathrm{e}^{-1}$ (Table 4).

\subsection{Technical and economic abatement scenarios}

The MACC (Fig. 2 and 3) shows that under the maximum technical abatement scenario for 2020 emission reduction amount to $402 \mathrm{MtCO}_{2} \mathrm{e}$, representing 34\% of BAU emissions. 149 and $253 \mathrm{MtCO}_{2} \mathrm{e}$ emissions could be avoided from croplands and livestock/grasslands, respectively. Without accounting for carbon sequestration in soils, the overall mitigation potential will stand at $207 \mathrm{MtCO}_{2} \mathrm{e}(\mathrm{Fig}$. 2). The results suggest that there is significant potential for win-win abatement avoiding emissions while providing financial savings. Fig. 2 and 3 illustrate that at national scale about $135 \mathrm{MtCO}_{2} \mathrm{e}$ emissions could be abated at negative costs, equivalent to $11 \%$ of baseline emissions in 2020 . If fully implemented, these win-win measures result in savings of $¥ 111$ billion (2010 price) for farmers. This analysis does not account for ancillary impacts such as reduced fertilizer production, government subsidies, or reduced environmental impacts. The analysis also shows that $176 \mathrm{MtCO}_{2} \mathrm{e}$ (approximately $44 \%$ of the total potential) emissions can be realized at a carbon price less than $¥ 100$ per $\mathrm{tCO}_{2} \mathrm{e}$. The most cost-beneficial measures are a) probiotics addition to the diet, b) fertilizer best management practices, c) animal breeding, and d) conservation tillage for upland crops. The MACC results highlight the importance of improved $\mathrm{N}$ fertilizer and manure management practices coupled with improved irrigation systems. 


\section{Discussion and conclusions}

Estimates presented here represent the first attempt to derive a bottom-up abatement potential for the agricultural sector in China, and have been conducted using a number of necessary data, assumptions and experimental evidence that may not always reflect the real biophysical heterogeneity in Chinese systems. These include the assumptions about baseline activity projections (including input and output prices), measure abatement rates and their implementation costs. But the MACC exercise aims to make these assumptions transparent and therefore provides a basis for on-going improvement of technical and economic mitigation estimates. We also suggest that the estimates provide useful pointers for both policy and research to realize the indicated potentials.

The observation of low and negative cost potential raises several behavioural and institutional issues, some of which have been addressed in relation to mitigation studies conducted elsewhere (Moran et al., 2013; Zhang et al., 2013), some of which are specific to the structure of Chinese agriculture and its role in national policy on both food security and rural development.

Although implementation of many mitigation measures could improve farm incomes, there are several possible explanations to why these apparently unrealized savings exist. First, farmers have entrenched views on the links between inputs and yields (Wu et al., 2011) and are generally risk-averse faced with new technologies and practices. Second, given the small scale of Chinese farms, savings from rationalizing $\mathrm{N}$ application rates are perceived to be relatively insignificant by farmers, particularly when fertilizer prices are kept low by subsidies (Zhang et al., 2013) that serve to maintain smallholder production. Third, increasing rural labor shortages raise the perceived opportunity cost of any time required for mitigation activities. Fourth, weak agricultural infrastructure and poor rural extension services are a hindrance to measure adoption. For example, although scientifically justified fertilizer recommendations have been developed for major crops and cropping systems (Zhang et al., 2009), the absence of good extension advice hinders information dissemination to millions of smallholder farms that constitute $90 \%$ of the sector. These farms are widely distributed, with low levels of mechanization. Equally, the poor supply of artificial insemination services to livestock farmers can be attributed to large distances between farms. A solution for this would be the implementation of a tight grid of breeding farms to cover the whole country. Alternatively, the challenge of implementing more efficient and environmentally sound practices could be solved by the consolidation of agricultural land and more ambitious government investment in infrastructure.

Beyond these challenges, the MACC results also highlight the significance of livestock emissions and potential in the analysis. An observation from policy statements is that Chinese policy makers tend to ignore the role of livestock in GHG mitigation. But since the sector will continue to extend its role as largest source of GHG emissions in Chinese agriculture, it is important to focus on this sector for extensive mitigation strategies. In line with the trend of shifting from small scale and outdoor livestock production to large scale indoor systems, the focus should therefore be on biomass gasification (L1), breeding techniques and advanced feeding technologies as tea saponins (L4), which will be most 
applicable for housed livestock (Grainger and Beauchemin, 2011). It is expected that this trend together with application of these technologies will increase productivity/profitability significantly, and hence be part of the solution to cope with the rapidly increasing demand for livestock products in China and shifting China's role from a net importer to an exporter of livestock products (Jouany and Morgavi, 2007).

The MACC suggests other numerous research priorities in terms of tailoring practices to local biophysical conditions, thus allowing a more accurate estimate of measure CE. The Chinese government has already initiated programs to improve domestic research in the field of climate change mitigation and agriculture. For example, the ongoing research project "Integration and demonstration of key carbon sequestration and mitigation technologies in agricultural ecosystems" accredited by the Chinese Ministry of Science and Technology for the 12th FYP period, aspires to identify appropriate mitigation measures for major cropping systems, to quantify abatement rates and to model mitigation potential at the regional scale.

More broadly, the economic potential identified is timely and potentially paves the way for identifying an agricultural contribution to national GHG reduction targets, either through offsetting projects, or eventually as part of other trading arrangements. The government has designated five cities (Beijing, Tianjin, Shanghai, Chongqing, and Shenzhen) and two provinces (Guangdong and Hubei) as the pilots to test carbon emission trading in October 2011 (NDRC, 2011b), and in June 2012, the Interim Voluntary Emission Reduction (VER) Rules (NDRC, 2012) were officially published to provide basis for project-based offset markets in China. The progress of domestic trading in China remains to be seen, although some commentators suggest that successful implementation could be a highly significant development in the path towards a global carbon market. The role of agriculture in the regime has not yet been discussed, although there are well-known obstacles in terms of monitoring, reporting and verification of emissions. Despite this, the MACC provides an initial indication of priority interventions for the design of efficient policy. 


\section{References:}

Akiyama, H., Yan, X.Y., Yagi, K., 2010. Evaluation of effectiveness of enhanced-efficiency fertilizers as mitigation options for $\mathrm{N} 2 \mathrm{O}$ and $\mathrm{NO}$ emissions from agricultural soils: meta-analysis. Global Change Biology 16, 1837-1846.

Beach, R. H., DeAngelo, B.J., Rose, S., Li, C.S, Salas, W., DelGrosso, S.J., 2008. Mitigation potential and costs for global agricultural greenhouse gas emissions. Agricultural Economics 38, 109-115.

Fu, C., Yu, G., 2010. Estimation and spatiotemporal analysis of methane emissions from agriculture in China. Environmental Management 46(4), 618-632.

Gao, B., Ju, X.T., Zhang, Q., Christie, P., Zhang, F.S., 2011. New estimates of direct N2O emissions from Chinese croplands from 1980 to 2007 using localized emission factors. Biogeosciences Discussions 8, 6971-7006.

Grainger, C., Beauchemin, K.A., 2011. Can enteric methane emissions from ruminants be lowered without lowering their production? Animal feed science and technology 166, 308-320.

Hang, T., Bu, M.D., Geng, W., 2012. Pollution status and biogas producing potential of livestock and poultry excrements in China. Chinese Journal of Ecology 31(5), 1241-1249.

Huang, J.K., Li, N.H., 2003. China's Agricultural Policy Simulation Model - CAPSiM. Journal of Nanjing Agricultural University (Social Sciences Edition) 3(2), 30-41.

Huang, Y., Tang, Y., 2010. An estimate of greenhouse gas (N2O and CO2) mitigation potential under various scenarios of nitrogen use efficiency in Chinese croplands. Global Change Biology 16, 2958-2970.

International Energy Agency (IEA), 2012. World Energy Outlook 2012. IEA Publications.

International Fertilizer Industry Association (IFA), 2013. IFADATA-N fertilizer consumption. http://www.fertilizer.org/ifa/ifadata/search. Accessed in June 2013.

IPCC, 2006. IPCC Guidelines for National Greenhouse Gas Inventories. IPCC/IGES, Hayama, Japan.

IPCC, 2007. Agriculture in: Climate Change 2007: Mitigation, Contribution of Working Group III to the Fourth Assessment Report of the Intergovernmental Panel on Climate Change (eds Metz B, David-son OR, Bosch PR et al.), pp. 498-540. Cambridge University Press, Cambridge, UK and New York, NY, USA.

Jouany, J.P., Morgavi, D.P., 2007. Use of 'natural' products as alternatives to antibiotic feed additives in ruminant production. Animal 1(10), 1443-1466.

Ju, X.T., Xing, G.X., Chen, X.P., Zhang, S.L., and Zhang, L.J., Liu, X.J., Cui, Z.L., Yin, B., Christie, P., Zhu, Z.L., and Zhang F.S., 2009. Reducing environmental risk by improving $N$ management in intensive Chinese agricultural systems. Proceedings of the National Academy of Sciences of the United States of America, 106, 3041-3046.

Lin, E.D., Li, Y.E., Guo, L.P., Gao, D.M., 2005. Chinese agricultural soils: carbon sequestration potentials and climate change. Science Press, Beijing. ISBN: 9787030125040 (in Chinese)

Lu, F., Wang, X.K, Han, B., Ouyang, Z., Duan, X., Zheng, H.U.A., Miao, H., 2009. Soil carbon sequestrations by nitrogen fertilizer application, straw return and no-tillage in China's cropland. Global Change Biology 15, 281-305.

Ministry of Agriculture (MOA), 2006. Sustainable development strategies of grassland in China. China Agriculture Press, Beijing. 
Ministry of Agriculture (MOA) of the P.R.C., 2007. National rural biogas digesters construction plan (2006-2010), Beijing. (In Chinese)

Ministry of Environmental Protection of People's Republic of China (MOEP) (2005 - 2011) Report on the State of the Environment of China, Beijing. (In Chinese)

Ministry of Agriculture (MOA) of the P.R.C., 2011. National Agriculture Mechanization Extension Plan (2011-2015), Beijing.

Ministry of Agriculture (MOA) of the P.R.C. 2011. 12 ${ }^{\text {th }}$ National Agriculture and Rural Economic Development Guidelines.

Ministry of Agriculture (MOA) of the P.R.C., 2001-2012a. China Rural Statistical Yearbook. China Agricultural Press, Beijing.

Ministry of Agriculture (MOA) of the P.R.C., 2001-2012b. China Livestock Yearbook. China Agricultural Press, Beijing.

Moran, D., MacLeod, M., Wall, E., Eory, V., McVittie, A., Barnes, A., Rees, R.M., Topp, C.E., Pajot, G., Matthews, R., Smith, P., Moxey, A., 2011. Developing carbon budgets for UK agriculture, land-use, land-use change and forestry out to 2022. Climatic Change 105, 529-553.

Moran, D., Lucas, A., Barnes. A., 2013. Mitigation win-win. Nature Climate Change 3(7), 611-613.

National Coordination Committee on Climate Change (NCCC), 2004. The People's Republic of China-Initial National Communication on Climate Change. China Planning Press, Beijing.

National Coordination Committee on Climate Change (NCCC), 2012. Second National Communication on Climate Change of the People's Republic of China. China Planning Press, Beijing.

National Development and Reform Committee (NDRC) of the P.R.C., 2007. Medium and Long-term development plan for renewable energy, Beijing.

National Development and Reform Committee (NDRC) of the P.R.C., 2011a. Implementation Plan on the Comprehensive Use of Crop Straw during the 12th Five-year Plan Period, Beijing.

National Development and Reform Committee (NDRC) of the P.R.C., 2011b. Notice on Carbon Emissions Trading System Pilots, Beijing.

National Development and Reform Committee (NDRC) of the P.R.C., 1998-2012. China Agricultural Products Cost-Benefit Yearbook. China Statistics Press, Beijing.

National Development and Reform Commission (NDRC), 2012. Interim Rules for Management of Voluntary Emission Reductions Transactions in China.

Nayak, D., Cheng, K., Wang, W., Moran, D., Yan, X.Y., Guo, M., Cardenas, L., Pan, G.X., Smith, P., 2013a. Technical Options to reduce greenhouse gas emission from rice agriculture in China (In submission)

Nayak, D.R. Smith, P., 2013b. Assessing greenhouse gas mitigation potential of Grasslands of China. (In submission).

Oenema, O., Velthof, G., Kuikman, P., 2001. Technical and policy aspects of strategies to decrease greenhouse gas emissions from agriculture. Nutrient Cycling in Agroecosystems 60, 301-315.

Patton, B.D., Dong, X., Nyren, P.E., Nyren, A., 2007. Effects of grazing intensity, precipitation, and temperature on forage production. Rangeland Ecology \& Management 60(6), 656-665. 
Pellerin, S., Bamière, L., Angers, D., Béline, F., Benoît, M., Butault, J.P., Chenu, C., Colnenne-David, C., De Cara, S., Delame, N., Doreau, M., Dupraz, P., Faverdin, P., Garcia-Launay, F., Hassouna, M., Hénault, C., Jeuffroy, M.H., Klumpp, K., Metay, A., Moran, D., Recous, S., Samson, E., Savini, I., Pardon, L., 2013. Quelle contribution de l'agriculture française à la réduction des émissions de gaz à effet de serre ? Potentiel d'atténuation et coût de dix actions techniques. Synthèse du rapport d'étude, INRA (France), 92 p.

Saetnan, E.R., Veneman, J.B., Newbold, C.J., 2013. Meta-analysis of mitigation options for enteric methane emissions from ruminants. (In submission).

Schulte, R., Crosson, P., Donnellan, T., Farrelly, N., Finnan, J., Lalor,L., Lanigan,G., O’Brien, D., Shalloo,L., Thorne, F.,2012. A Marginal Abatement Cost Curve for Irish Agriculture. Teagasc submission to the National Climate Policy Development Consultation.

Smith, P., Martino, D., Cai, Z., Gwary, D., Janzen, H., Kumar, P., McCarl, B., Ogle, S., O’Mara, F., Rice, C., Scholes, B., Sirotenko, O., Howden, M., McAllister, T., Pan, G., Romanenkov, V., Schneider, U., Towprayoon, S., Wattenbach, M., Smith, J., 2008. Greenhouse gas mitigation in agriculture. Philosophical Transactions of the Royal Society B: Biological Sciences 363, 789-813.

Smith, P., Haberl, H., Popp, A., Erb, K., Lauk, C., Harper, R., Tubiello, F.N., De Siqueira Pinto, A., Jafari, M., Sohi, S., Masera, O., Böttcher, H., Berndes, G., Bustamante, M., Ahammad, H., Clark, H., Dong, H., Elsiddig, E.A., Mbow, C., Ravindranath, N.H., Rice, C.W., Robledo Abad, C., Romanovskaya, A., Sperling, F., Herrero, M., House, J.I., Rose, S., 2013. How much land-based greenhouse gas mitigation can be achieved without compromising food security and environmental goals? Global Change Biology 19, 2285-2302.

State Council of the P.R.C., 2012. National Agricultural Water-Saving Outline (2012-2020), Beijing.

Wang, F.H., Ma, W.Q., Doum Z.X., Mam L., Lium X.L., Xum J.X., Zhangm F.S., 2006. The estimation of the production amount of animal manure and its environmental effect in China. China Environmental Science 26, 614-617. (In Chinese)

Wang, F., Dou, Z., Ma, L., Ma, W., Sims, J. T., Zhang, F., 2010. Nitrogen mass flow in China's animal production system and environmental implications. Journal of Environmental Quality 39(5), 1537-1544.

Wreford, A.D., Moran, D., Adger, N., 2010. Climate Change and Agriculture: Impacts, Adaptation and Mitigation. OECD Publishing.

Wu, J.P., Michalk, D., Kemp, D., Lian, Y., Xuyin, G., 2011. Talking with China's livestock herders: What was learnt about their attitudes to new practices. Development of sustainable livestock systems on grasslands in north-western China. Canberra: ACIAR Proceedings, pp. 162-176.

Zhang, F.S., Chen, X.P., Chen, Q., 2009. Fertilization guidelines for major crops in China. China' Agriculture University Press, Beijing. (In Chinese)

Zhang, W., Yu, Y., Huang, Y., Li, T., Wang, P., 2011. Modeling methane emissions from irrigated rice cultivation in China from 1960 to 2050. Global Change Biology 17, 3511-3523.

Zhang, F.S, Cui, Z.L., Chen, X.P., Ju, X.T., Shen, J., Chen, Q., Liu, X., Zhang, W.F., Mi, G., Fan, M., Jiang, R., 2012a. Chapter one - Integrated Nutrient Management for Food Security and Environmental Quality in China, in: Sparks, D.L. (Ed.), Academic Press, pp. 1-40.

Zhang, T., Bu, M.D., Geng, W., 2012b. Pollution status and biogas producing potential of livestock and poultry excrements in China. Chinese Journal of Applied Ecology 23, 2015-2025. (In Chinese)

Zhang, W.F., Dou, Z.X., He, P., Ju, X.T., Powlson, D., Chadwick, D., Norse, D., Lu, Y.L., Zhang, Y., Wu, L., Chen, X.P., Cassman, K.G., Zhang, F.S., 2013. New technologies reduce greenhouse gas emissions from nitrogenous fertilizer in China. Proceedings of the National Academy of Sciences 110, 8375-8380. 
Zou, J., Huang, Y., Qin, Y.M., Liu, S.W., Shen, Q.R., Pan, G.X., Lu, Y.Y., LiuU, Q.H., 2009. Changes in fertilizer-induced direct $\mathrm{N} 2 \mathrm{O}$ emissions from paddy fields during rice-growing season in China between 1950s and 1990s. Global Change Biology 15, 229-242. 


\begin{tabular}{|c|c|c|c|}
\hline No. & Measure & Explanations & Target crops \\
\hline $\mathrm{C} 1$ & $\begin{array}{l}\text { Fertilizer best management } \\
\text { practices - Right rate }\end{array}$ & $\begin{array}{l}\text { Reduce gross overuse of } \mathrm{N} \text { fertilizers amount. We set regional optimal } \mathrm{PFP}_{\mathrm{N}} * \text { (Partial Factor Productivity of } \mathrm{N} \\
\text { fertilizer) derived from scientific fertilization recommendations (Zhang et al., 2009) as the indicator for fertilizer } \\
\text { efficiency improvement objectives. This measure calls for a direct reduction in } \mathrm{N} \text { fertilizer use for certain crops in } \\
\text { targeted provinces to raise regional } \mathrm{PFP}_{\mathrm{N}} \text { to } 70 \% \text { of the optimal levels (Table C.1). }\end{array}$ & $\begin{array}{l}\text { Rice, wheat, } \\
\text { maize, } \\
\text { vegetable, fruit }\end{array}$ \\
\hline $\mathrm{C} 2$ & $\begin{array}{l}\text { Fertilizer best management } \\
\text { practices (Wheat \&Maize) - } \\
\text { Right time and right } \\
\text { placement }\end{array}$ & $\begin{array}{l}\text { This strategy suggests postponing } \mathrm{N} \text { fertilizer to a later stage of wheat and maize growth with preferably two } \\
\text { top-dressings compared to the current one top-dressing practice, and popularizing fertilizer deep placement by } \\
\text { using appropriate machines for maize top-dressing, in a bid to reach optimal } \text { PFP }_{N} \text { (or optimum } \mathrm{N} \text { management) by } \\
\text { increasing yield and reducing } \mathrm{N} \text { losses and further decreasing } \mathrm{N} \text { rate(Table C.1). }\end{array}$ & Wheat, maize \\
\hline $\mathrm{C} 3$ & $\begin{array}{l}\text { Fertilizer and water best } \\
\text { management in rice paddies }\end{array}$ & $\begin{array}{l}\text { Split the total amount of } \mathrm{N} \text { fertilizers into at least three applications for basal fertilization, early tillering, panicle } \\
\text { initiation and heading stages; and shift from mid-season drainage (F-D-F) to intermittent irrigation (F-D-F-M). }\end{array}$ & Rice \\
\hline $\mathrm{C} 4$ & $\begin{array}{l}\text { Fertilizer best management } \\
\text { practices (cash crops) - Right } \\
\text { products, right time and right } \\
\text { placement }\end{array}$ & $\begin{array}{l}\text { Promote fertiligation (e.g. drip irrigation together with soluble fertilizers) for vegetables and cotton to save both } \\
\text { fertilizer and irrigation inputs. As to fruits, controlling } \mathrm{N} \text { rate and adjusting fertilization periods are essential to } \\
\text { achieve sustainable fruit production. In addition, replacing part of ammonium-based fertilizers with nitrate-based } \\
\text { products can also contribute to minimizing } \mathrm{N}_{2} \mathrm{O} \text { emissions and enhancing productivity. }\end{array}$ & $\begin{array}{l}\text { Cotton, } \\
\text { vegetable, fruit }\end{array}$ \\
\hline $\mathrm{C} 5$ & $\begin{array}{l}\text { Enhanced-efficiency } \\
\text { fertilizers }\end{array}$ & $\begin{array}{l}\text { Use fertilizers added with nitrification inhibitors (NI) and/or urease inhibitors (UI) and slow- and controlled- } \\
\text { fertilizers to reduce } \mathrm{N}_{2} \mathrm{O} \text { emissions. }\end{array}$ & $\begin{array}{l}\text { All crops, } \\
\text { vegetable, fruit }\end{array}$ \\
\hline C6 & $\begin{array}{l}\text { More efficient recycling of } \\
\text { organic manure }\end{array}$ & $\begin{array}{l}\text { The general objective is to increase animal manure amendment to soils to supply } 30 \% \text { of crop N nutrients demand } \\
\text { and } 50 \% \text { of vegetables and fruit. Efficient recycling of animal manure should be in form of composed manure or } \\
\text { biodigester residues to replace part of synthetic } \mathrm{N} \text { fertilizers. }\end{array}$ & $\begin{array}{l}\text { All crops, open } \\
\text { field vegetable, } \\
\text { fruit }\end{array}$ \\
\hline $\mathrm{C} 7$ & $\begin{array}{l}\text { Conservation tillage for } \\
\text { upland crops }\end{array}$ & $\begin{array}{l}\text { Conservation tillage }(\mathrm{CT}) \text { is a series of agricultural practices aiming to reduce tillage and soil disturbance to a } \\
\text { minimum extent with at least } 30 \% \text { of residues incorporated into soil to increase soil carbon content in upland } \\
\text { cropping systems. }\end{array}$ & Wheat, maize \\
\hline $\mathrm{C} 8$ & Straw return in upland crops & $\begin{array}{l}\text { Returning straw or residue back to field is considered a stand-alone farming practice in China which only involves } \\
\text { changes in straw management compared with CT measure. This technique is an important way to improve soil } \\
\text { fertility and soil physical properties if properly tailored to different cropping systems and local farming practices. }\end{array}$ & Wheat, maize \\
\hline C9 & Biochar addition & $\begin{array}{l}\text { Application of biochar produced with crop straw pyrolysis can significantly decrease } \mathrm{N}_{2} \mathrm{O} \text { emissions and improve } \\
\text { soil prosperities to enhance yields. }\end{array}$ & $\begin{array}{l}\text { Rice, wheat, } \\
\text { maize }\end{array}$ \\
\hline
\end{tabular}

${ }^{*} \mathrm{PFP}_{\mathrm{N}}-$ Partial Factor Productivity of $\mathrm{N}$ fertilizer is an indicator of $\mathrm{N}$ use efficiency, measured by the grain yield per $\mathrm{N}$ input $\left(\mathrm{kg} \mathrm{kgN}^{-1}\right)$ 


\begin{tabular}{|c|c|c|c|}
\hline No. & Measure & Explanations & Target species \\
\hline L1 & $\begin{array}{l}\text { Anaerobic digestion of } \\
\text { manure }\end{array}$ & $\begin{array}{l}\text { Implementation of on farm anaerobic digesters for storing livestock manure residues and converting some } \\
\text { of the organic content to } \mathrm{CH}_{4} \cdot \mathrm{CH}_{4} \text { can be burned to produce heat or electricity for the livestock farm or } \\
\text { sold to other consumers. }\end{array}$ & $\begin{array}{l}\text { Cattle, dairy cows, pigs, } \\
\text { poultry }\end{array}$ \\
\hline $\mathrm{L} 2$ & Animal breeding & $\begin{array}{l}\text { Breeding techniques like artificial insemination of domestic livestock with high quality semen from } \\
\text { breeding stock will generate a trade-off between decreasing rumen } \mathrm{CH}_{4} \text { production and improved feed } \\
\text { intake, milk production, weight gain and production efficiency. This measure does not consider cross } \\
\text { breeding. }\end{array}$ & $\begin{array}{l}\text { Indoor - cattle, dairy cows, } \\
\text { pigs, sheep, goat }\end{array}$ \\
\hline L3 & $\begin{array}{l}\text { Tea saponins addition to } \\
\text { the diet }\end{array}$ & $\begin{array}{l}\text { Tea saponins are plant secondary compounds that are available in highly concentrated form in waste by } \\
\text { products of tea production. Adding tea saponins to the diet of livestock is considered to increase the } \\
\text { productivity while reducing rumen } \mathrm{CH}_{4} \text { production. }\end{array}$ & $\begin{array}{l}\text { Indoor - cattle, dairy cows, } \\
\text { sheep and goat }\end{array}$ \\
\hline L4 & $\begin{array}{l}\text { Probiotics addition to the } \\
\text { diet }\end{array}$ & $\begin{array}{l}\text { Probiotics are commonly used in Chinese aquaculture industry but the application is uncommon for } \\
\text { terrestrial livestock. Adding probiotics to the diet modifies the rumen ecosystem and thereby reduce the } \\
\mathrm{CH}_{4} \text { production as well as improve the animal productivity and immune response. }\end{array}$ & $\begin{array}{l}\text { Indoor - cattle, dairy cows, } \\
\text { sheep and goat }\end{array}$ \\
\hline L5 & Lipid addition to the diet & $\begin{array}{l}\text { Adding polyunsaturated fatty acids to the diet of livestock can effectively reduce the } \mathrm{CH}_{4} \text { production } \\
\text { through suppression of rumen protozoa and inhibition of methanogens in the rumen and increase the } \\
\text { productivity of the animal. }\end{array}$ & $\begin{array}{l}\text { Indoor - cattle, dairy cows, } \\
\text { sheep and goat }\end{array}$ \\
\hline L6 & $\begin{array}{l}\text { Grazing prohibition for } \\
35 \% \text { of grazed grasslands }\end{array}$ & $\begin{array}{l}\text { Grazing ban is a common technique in grazing systems for improving degraded grasslands. This measure } \\
\text { considers a ban of } 35 \% \text { of the total grazed grassland in China. While the vegetation type is recovering, the } \\
\text { dry matter production is improving. The grass will not be cut and thus grass residues can enter the soil to } \\
\text { improve the soil organic matter content and increase the carbon sequestration rate. }\end{array}$ & $\begin{array}{l}\text { Grazing - cattle, dairy } \\
\text { cows, sheep and goats }\end{array}$ \\
\hline L7 & $\begin{array}{l}\text { Reduction of stocking } \\
\text { rate - medium grazing } \\
\text { intensity }\end{array}$ & $\begin{array}{l}\text { Chinese grasslands are usually overgrazed. This measure considers a stocking rate reduction to a medium } \\
\text { intensity. While the grassland condition is improving, the dry matter production of the grasslands would } \\
\text { increase by } 10 \% \text {. The grassland utilization rate is reduced to } 50 \% \text { and thus the higher amount of organic } \\
\text { material entering the soil will increase the carbon sequestration rate. }\end{array}$ & $\begin{array}{l}\text { Grazing - cattle, dairy } \\
\text { cows, sheep and goats }\end{array}$ \\
\hline L8 & $\begin{array}{l}\text { Reduction of stocking } \\
\text { rate - light grazing } \\
\text { intensity }\end{array}$ & $\begin{array}{l}\text { This measure considers a light grazing intensity on Chinese grasslands. As a result the grassland utilization } \\
\text { rate is reduced to } 35 \% \text { and the dry matter production increases by } 3 \% \text {. Similar to L9, the carbon } \\
\text { sequestration rate increases due to a higher organic matter input to the soil. }\end{array}$ & $\begin{array}{l}\text { Grazing - cattle, dairy } \\
\text { cows, sheep and goats }\end{array}$ \\
\hline
\end{tabular}


Table 2a Cost considerations of cropland measure implementation

\begin{tabular}{|c|c|c|c|c|c|c|c|c|}
\hline \multirow{2}{*}{$\begin{array}{l}\text { Measure } \\
\text { No. }\end{array}$} & \multirow{2}{*}{$\begin{array}{l}\text { Target } \\
\text { crops }\end{array}$} & \multicolumn{6}{|c|}{ Cost consideration factors (2010 level per hectare per cropping season) } & \multirow[t]{2}{*}{$\begin{array}{l}\text { Incurring } \\
\text { frequency }\end{array}$} \\
\hline & & $\begin{array}{l}\text { Fertilizer rate } \\
\text { and price }\end{array}$ & $\begin{array}{l}\text { Labor } \\
\text { (mandays) }\end{array}$ & Machinery & Irrigation & Other costs & Yield & \\
\hline \multirow[t]{2}{*}{$\mathrm{C} 1$} & $\begin{array}{l}\text { Cereal } \\
\text { crops }\end{array}$ & $\begin{array}{l}\mathrm{N} \text { rate: rice }-15 \% \\
\text { wheat- } 31 \% \\
\text { maize- } 16 \%\end{array}$ & & & & & & $\begin{array}{l}\text { Cropping } \\
\text { season }\end{array}$ \\
\hline & $\begin{array}{l}\text { Cash } \\
\text { crops }\end{array}$ & $\begin{array}{l}\mathrm{N} \text { rate: } \\
\text { greenhouse veg. } \\
-15 \% \text { openfield } \\
\text { veg. }-10 \% \\
\text { fruit- } 15 \%\end{array}$ & & & & & & $\begin{array}{l}\text { Cropping } \\
\text { season }\end{array}$ \\
\hline \multirow[t]{2}{*}{$\mathrm{C} 2$} & Wheat & $\mathrm{N}$ rate: $-20 \%$ & +7.5 & & & & $+5 \%$ & $\begin{array}{l}\text { Cropping } \\
\text { season }\end{array}$ \\
\hline & Maize & $\mathrm{N}$ rate: $-18 \%$ & & $¥ 225$ & & & $+8 \%$ & $\begin{array}{l}\text { Cropping } \\
\text { season }\end{array}$ \\
\hline C3 & Rice & $\mathrm{N}$ rate: $-20 \%$ & +15 & & $-20 \%$ & & $+5 \%$ & $\begin{array}{l}\text { Cropping } \\
\text { season }\end{array}$ \\
\hline \multirow[t]{3}{*}{$\mathrm{C} 4$} & Vegetable & $\begin{array}{l}\text { N rate: } \\
\text { greenhouse } \\
-27 \% \text {; openfield } \\
-24 \% \text {. } \\
\text { Nitrate-based } \\
\text { fertilizer }(10 \mathrm{~kg} \\
\mathrm{N}) \text { price:+60\% } \\
\text { higher }\end{array}$ & -15 & & $-40 \%$ & $\begin{array}{l}\text { Drip irrigation } \\
¥ 3000 \text {; agri. } \\
\text { film } ¥ 1000\end{array}$ & $+10 \%$ & $\begin{array}{l}\text { Cropping } \\
\text { season }\end{array}$ \\
\hline & Fruit & $\begin{array}{l}\text { N rate: }-30 \% \text {. } \\
17 \mathrm{kgN} \\
\text { price: } 60 \% \\
\text { higher }\end{array}$ & +45 & & & & $+10 \%$ & Annual \\
\hline & Cotton & $\begin{array}{l}\text { N rate: }-33 \% \text {. } \\
17 \mathrm{kgN} \\
\text { price: } 60 \% \\
\text { higher }\end{array}$ & -30 & & $-40 \%$ & $\begin{array}{l}\text { Drip irrigation } \\
¥ 3000 \text {; agri. } \\
\text { film } ¥ 1000 \text {; } \\
\text { pesticide }-30 \%\end{array}$ & $+10 \%$ & Annual \\
\hline $\mathrm{C} 5$ & All crops & $\begin{array}{l}\mathrm{N} \text { fertilizer } \\
\text { price: } 10 \% \\
\text { higher }\end{array}$ & & & & & & Annual \\
\hline \multirow[t]{3}{*}{ C6 } & $\begin{array}{l}\text { Cereal } \\
\text { crops }\end{array}$ & $\begin{array}{l}\mathrm{N} \text { rate: rice }-11 \% \\
\text { wheat- } 10 \% \\
\text { maize }-9 \% \text {. } \\
\text { Organic } \\
\text { manure }^{\dagger}:+1.6-2 \\
\text { t/ha at } ¥ 500 / \mathrm{t}\end{array}$ & +7.5 & & & & & Annual \\
\hline & $\begin{array}{l}\text { Openfield } \\
\text { vegetable }\end{array}$ & $\begin{array}{l}\mathrm{N} \text { rate: }-7 \% \text {. } \\
\text { Organic } \\
\text { manure: }+1.52 \\
\text { t/ha }\end{array}$ & +7.5 & & & & & \\
\hline & Fruit & $\begin{array}{l}\text { N rate: }-11 \% \text {. } \\
\text { Organic } \\
\text { manure: }+5.16 \\
\text { t/ha }\end{array}$ & +15 & & & & & \\
\hline C7 & $\begin{array}{l}\text { Wheat, } \\
\text { maize }\end{array}$ & & $-30 \%$ & $-20 \%$ & & $\begin{array}{l}\text { Seed }+10 \% \\
\text { pesticide }+30 \%\end{array}$ & & $\begin{array}{l}3 \text { years or } \\
4 \text { years }\end{array}$ \\
\hline $\mathrm{C} 8$ & $\begin{array}{l}\text { Wheat, } \\
\text { maize }\end{array}$ & $+30 \mathrm{~kg} / \mathrm{ha}$ & & $¥ 300$ & & $\begin{array}{l}\text { Seed }+10 \% \\
\text { pesticide }+30 \%\end{array}$ & & $\begin{array}{l}\text { Cropping } \\
\text { season }\end{array}$ \\
\hline C9 & $\begin{array}{l}\text { Rice, } \\
\text { wheat, } \\
\text { maize }\end{array}$ & $\begin{array}{l}\text { 20t/ha at } ¥ 1000 \\
\text { /t biochar }\end{array}$ & +15 & & & & $+10 \%$ & $\begin{array}{l}\text { Every } 5 \\
\text { years }\end{array}$ \\
\hline
\end{tabular}

${ }^{*} \mathrm{~N}$ rates in the table are those in measure target regions or balanced $\mathrm{N}$ application rates.

${ }^{\dagger}$ Here the $\mathrm{N}$ content in typical organic manure fertilizers stands at $1.2 \%$. 
Table 3b Cost considerations of livestock measure implementation

\begin{tabular}{|c|c|c|c|c|c|c|}
\hline \multirow[b]{2}{*}{$\begin{array}{l}\text { Measure } \\
\text { No. }\end{array}$} & \multirow[b]{2}{*}{ Target animals } & \multicolumn{4}{|c|}{$\begin{array}{c}\text { Cost consideration factors (2010 level per sheep unit per } \\
\text { year) }\end{array}$} & \multirow[b]{2}{*}{$\begin{array}{l}\text { Application } \\
\text { rate }\end{array}$} \\
\hline & & $\begin{array}{l}\text { Investment } \\
\text { costs } \\
\left(\text { year }^{-1}\right)\end{array}$ & $\begin{array}{l}\text { Administration } \\
\text { cost }\end{array}$ & revenue & $\begin{array}{l}\text { Yield } \\
\text { increase } \\
\left(\text { head }^{-1}\right)\end{array}$ & \\
\hline $\mathrm{L} 1$ & $\begin{array}{l}\text { Cattle, dairy cows, } \\
\text { pigs, sheep, goat, } \\
\text { poultry }\end{array}$ & $¥ 3250$ & not available & $¥ 500 /$ year & & $\begin{array}{l}\text { Every } 15 \\
\text { years }\end{array}$ \\
\hline $\mathrm{L} 2$ & $\begin{array}{l}\text { Indoor - cattle, dairy } \\
\text { cows, pigs, sheep, goat }\end{array}$ & $¥ 60 /$ head & $¥ 20 /$ head & & $1 \%$ & Annual \\
\hline L3 & $\begin{array}{l}\text { Indoor - cattle, dairy } \\
\text { cows, pigs, sheep, goat }\end{array}$ & $¥ 1 /$ head & $¥ 2 /$ head/year & & $3-4 \%$ & Daily \\
\hline L4 & $\begin{array}{l}\text { Indoor - cattle, dairy } \\
\text { cows, sheep, goat }\end{array}$ & $¥ 18 /$ head & $¥ 2 /$ head/year & & $6 \%$ & Daily \\
\hline L5 & $\begin{array}{l}\text { Indoor - cattle, dairy } \\
\text { cows, sheep, goat }\end{array}$ & $¥ 219 /$ head & $¥ 2 /$ head/year & & $2-4 \%$ & Daily \\
\hline L6 & $\begin{array}{l}\text { Grazing - cattle, dairy } \\
\text { cows, sheep, goats }\end{array}$ & $*$ & $*$ & & $1 \%^{\dagger}$ & Annual \\
\hline L7 & $\begin{array}{l}\text { Grazing - cattle, dairy } \\
\text { cows, sheep, goats }\end{array}$ & $*$ & $*$ & & $10 \%{ }^{\dagger}$ & Annual \\
\hline L8 & $\begin{array}{l}\text { Grazing - cattle, dairy } \\
\text { cows, sheep, goats }\end{array}$ & $*$ & $*$ & & $3 \%{ }^{\dagger}$ & Annual \\
\hline
\end{tabular}

\footnotetext{
* We assume free grazing on pasture which is most common in Chinese grassland systems. Additionally, we do not assume construction of new warm shed since the Chinese government increases the housing capacities strongly each year. Therefore, only costs regarding additional feeding and running housing facilities are applied.

${ }^{\dagger}$ Increase of DM production /ha based on Patton et al. (2007).
} 
Table 4a Mitigative effects and stand-alone abatement rates of cropland mitigation measures

\begin{tabular}{|c|c|c|c|c|c|c|c|c|c|c|c|}
\hline \multirow[b]{2}{*}{$\begin{array}{l}\text { Measure } \\
\text { No. }\end{array}$} & \multicolumn{3}{|c|}{ Mitigative effects } & \multicolumn{8}{|c|}{ Stand alone abatement rate $\left(\mathrm{tCO}_{2} \mathrm{e} \mathrm{ha}^{-1}\right)$} \\
\hline & $\mathrm{N}_{2} \mathrm{O}$ & $\mathrm{CH}_{4}$ & SOC & Rice & Wheat & Maize & $\begin{array}{l}\text { Other upland } \\
\text { crops }\end{array}$ & $\begin{array}{c}\text { Greenhouse } \\
\text { vegetable }\end{array}$ & $\begin{array}{l}\text { Openfield } \\
\text { vegetable }\end{array}$ & Fruit & Averaged \\
\hline $\mathrm{C} 2$ & - & & & & 0.190 & 0.208 & & & & & 0.201 \\
\hline $\mathrm{C} 3$ & - & - & & 1.337 & & & & & & & 1.337 \\
\hline C5 & - & & & 0.127 & 0.273 & 0.256 & 0.274 & 0.667 & 0.369 & 0.616 & 0.271 \\
\hline C6 & + & $+{ }^{*}$ & + & 0.460 & 0.689 & 0.574 & 0.631 & & 0.227 & 0.462 & 0.596 \\
\hline C7 & + & & + & & 0.611 & 0.611 & & & & & 0.611 \\
\hline $\mathrm{C} 8$ & + & & + & & 0.263 & 0.263 & & & & & 0.263 \\
\hline
\end{tabular}

Notes: + denotes reduced emissions or enhanced removal (positive mitigative effect);

- denotes increased emissions or suppressed removal (negative mitigative effect);

${ }^{*}$ Here $\mathrm{CH}_{4}$ emissions increase is only applied to rice paddies.

Table $3 \mathrm{~b}$ Mitigative effects and stand-alone abatement rates of livestock mitigation measures

\begin{tabular}{|c|c|c|c|c|c|c|c|c|c|c|c|}
\hline \multirow[b]{2}{*}{$\begin{array}{l}\text { Measure } \\
\text { No. }\end{array}$} & \multicolumn{3}{|c|}{ Mitigative effects } & \multicolumn{8}{|c|}{ Abatement rate (per year) } \\
\hline & $\mathrm{N}_{2} \mathrm{O}$ & $\mathrm{CH}_{4}$ & SOC & $\begin{array}{l}\text { Cattle } \\
\left(\% \mathrm{hd}^{-1}\right)\end{array}$ & $\begin{array}{l}\text { Dairy } \\
\text { cow }(\% \\
\left.\text { hd }^{-1}\right)\end{array}$ & $\begin{array}{l}\text { Pig }(\% \\
\left.h^{-1}\right)\end{array}$ & $\begin{array}{l}\text { Sheep } \\
\left(\% \mathrm{hd}^{-1}\right)\end{array}$ & $\begin{array}{l}\text { Goat } \\
\left(\% \mathrm{hd}^{-1}\right)\end{array}$ & $\begin{array}{l}\text { Average } \\
\left(\% \mathrm{hd}^{-1}\right)\end{array}$ & $\begin{array}{l}\text { Grassland } \\
\left(\mathrm{tCO}_{2} \mathrm{e}\right. \\
\left.\mathrm{ha}^{-1}\right)\end{array}$ & $\begin{array}{l}\text { Anaerobic } \\
\text { digester }\left(\mathrm{tCO}_{2} \mathrm{e}\right. \\
\left.\text { digester }^{-1}\right)\end{array}$ \\
\hline L1 & + & + & & & & & & & & & 2 \\
\hline L2 & & + & & -11 & 6 & 4 & 8 & 8 & 4 & & \\
\hline L3 & & + & & 12 & 15 & & 17 & 17 & 15 & & \\
\hline L4 & & + & & -0.2 & 0.3 & & 1 & 1 & 1 & & \\
\hline L5 & & + & & 8 & 6 & & 4 & 4 & 4 & & \\
\hline L6 & + & + & + & & & & & & & 1.07 & \\
\hline L7 & + & + & + & & & & & & & 0.70 & \\
\hline L8 & + & + & + & & & & & & & 0.88 & \\
\hline
\end{tabular}


Table 5 Average abatement rate, cost, $\mathrm{CE}$ and mitigation potential of mitigation measures

\begin{tabular}{|c|c|c|c|c|c|c|c|}
\hline \multirow[b]{2}{*}{$\begin{array}{l}\text { Measure } \\
\text { No. } \\
\end{array}$} & \multicolumn{2}{|c|}{$\begin{array}{l}\text { Abatement rate (in } \\
\text { 2020) }\end{array}$} & \multicolumn{2}{|c|}{ Cost (in 2020) } & \multirow{2}{*}{$\begin{array}{l}\text { Cost } \\
\text { effectiveness } \\
\text { (in 2020) } \\
¥ \mathrm{tCO}_{2} \mathrm{e}^{-1} \text {, } \\
2010 \text { price) }\end{array}$} & \multirow{2}{*}{$\begin{array}{l}\text { Additional } \\
\text { application } \\
\text { (in 2020) } \\
\text { (M ha) }\end{array}$} & \multirow{2}{*}{$\begin{array}{l}\text { Mitigation } \\
\text { potential } \\
\text { (in 2020) } \\
\left(\mathrm{MCO}_{2} \mathrm{e}\right)\end{array}$} \\
\hline & $\begin{array}{l}\left(\mathrm{tCO}_{2} \mathrm{e}\right. \\
\left.\mathrm{ha}^{-1}\right) \\
\end{array}$ & $\begin{array}{l}\left(\mathrm{CO}_{2} \mathrm{e}\right. \\
\text { reduction } \\
\left.\text { in } \% \mathrm{SU}^{-1}\right)\end{array}$ & $\begin{array}{l}\left(¥ \text { ha }^{-1},\right. \\
2010 \text { price) }\end{array}$ & $\begin{array}{l}¥ \mathrm{SU}^{-1}, \\
2010 \\
\text { price) }\end{array}$ & & & \\
\hline$\overline{\mathrm{C} 1}$ & 0.412 & & -228 & & -435 & 58.63 & 30.65 \\
\hline $\mathrm{C} 2$ & 0.201 & & -620 & & -3085 & 56.65 & 11.38 \\
\hline $\mathrm{C} 3$ & 1.337 & & 464 & & 347 & 17.93 & 23.98 \\
\hline $\mathrm{C} 4$ & 1.219 & & -2295 & & -1883 & 17.94 & 21.86 \\
\hline $\mathrm{C} 5$ & 0.271 & & 63 & & 231 & 57.23 & 15.54 \\
\hline C6 & 0.596 & & 527 & & 1576 & 120.11 & 40.19 \\
\hline $\mathrm{C} 7$ & 0.489 & & -107 & & -1692 & 22.98 & 1.46 \\
\hline $\mathrm{C} 8$ & 0.21 & & 70 & & 2209 & 30.06 & 0.95 \\
\hline C9 & 0.329 & & 1804 & & 5478 & 9.9 & 3.26 \\
\hline L1 & $2 *$ & & $-500 *$ & & -32 & $\ddagger$ & 58.66 \\
\hline L2 & & 4.1 & & -29 & -2571 & $\$$ & 4.4 \\
\hline L3 & & 15.4 & & -3.4 & -56 & $\$$ & 5.53 \\
\hline L4 & & 0.6 & & -17 & -7079 & $\sharp$ & 1.09 \\
\hline L5 & & 14.3 & & 109 & 1950 & $\sharp$ & 30.76 \\
\hline L6 & 1.067 & & 300 & & 281 & 56.98 & 60.78 \\
\hline L7 & 0.705 & & 45 & & 64 & 57.85 & 40.77 \\
\hline$\underline{\mathrm{L} 8}$ & 0.877 & & 283 & & 322 & 57.85 & 50.72 \\
\hline
\end{tabular}

* Per anaerobic digester

${ }^{\dagger}$ Sheep unit (SU) is a standard unit to compare different animal species. The conversion is sheep: 1, goat: 0.9, cattle: 5 , dairy cow: 7 , pig: 0.8 . It is only an approximate simplification and normally applied in grazing systems. Hence the costs $\mathrm{SU}^{-1}$ should be interpreted with caution.

${ }^{*}$ See Annex Table A.10 for application potential 


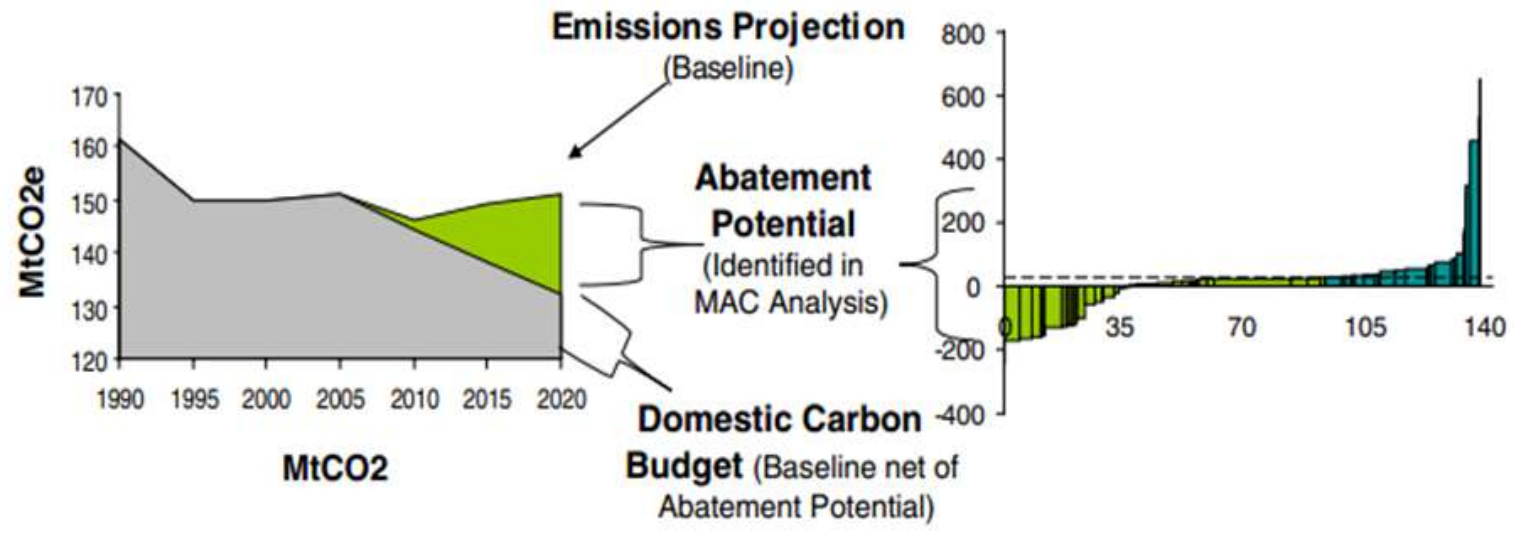

Fig.1 Illustration of the national economic abatement potential derived by the MACC exercise (left) and a "bottom-up" MACC showing its relationship to a sector carbon budget (right side). Source: Moran et al. (2011) 


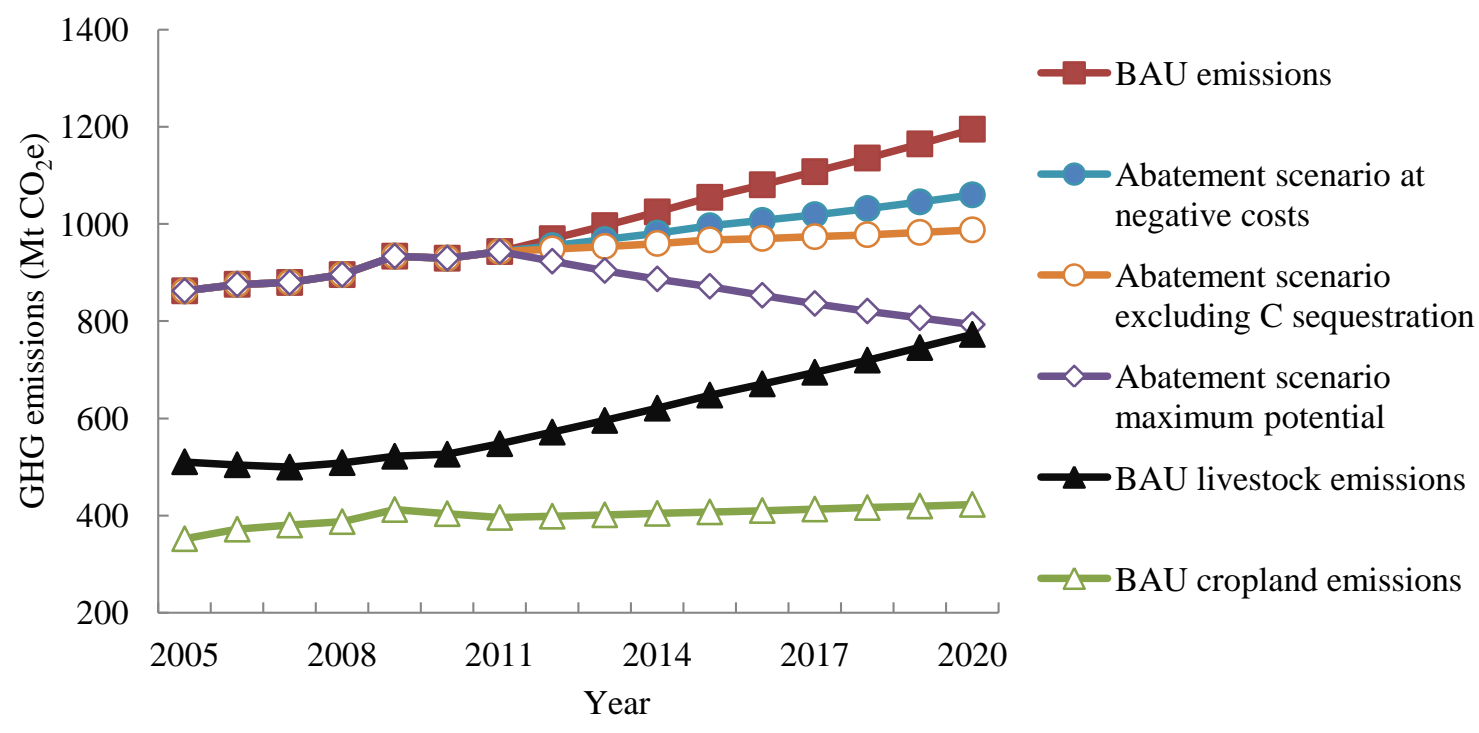

Fig. 2 Projected BAU and abatement emissions scenarios. BAU emissions are the sum of soil $\mathrm{N}_{2} \mathrm{O}$ emissions, rice $\mathrm{CH}_{4}$ emissions, ruminant $\mathrm{CH}_{4}$ emissions and waste management $\mathrm{N}_{2} \mathrm{O}$ and $\mathrm{CH}_{4}$ emissions. Mitigation potentials at maximum feasible application, negative cost scenarios and the scenario excluding carbon sequestration were identified from data in Fig. 3 assuming a linear adoption over time. 


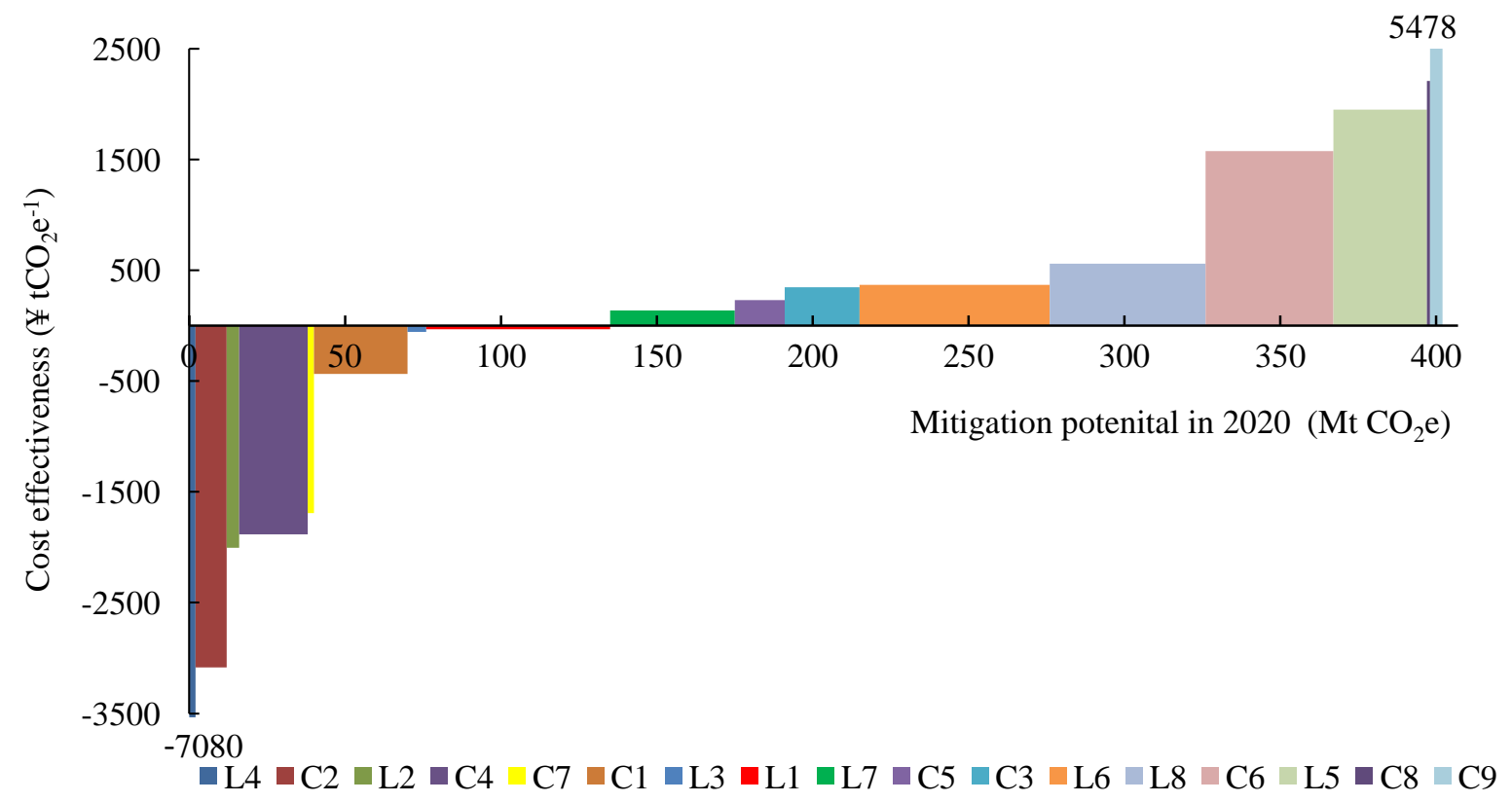

Fig. 3 MACC for China agricultural sector: maximum feasible abatement potential in 2020 (discount rate $=7 \%$ ). Measures codes refer to measures in Table 1: L4- Probiotics addition to the diet; C2- Fertilizer best management practices (Wheat \&Maize) - Right time and right placement; L2- Purebred breeding of livestock; C4-Fertilizer best management practices (cash crops) - Right product, right time and right placement; $\mathrm{C} 7$ - Conservation tillage for upland crops; C1-Fertilizer best management practices - Right rate; L3- Tea saponins addition to the diet; L1- Anaerobic digestion of manure; L7-Reduction of stocking rate - medium grazing intensity; C5-Enhanced-efficiency fertilizers; C3- Fertilizer and water best management in rice paddies; L6- Grazing prohibition for 35\% of grazed grasslands; L8- Reduction of stocking rate - light grazing intensity; C6- More efficient recycling of organic manure; L5- Lipid addition to the diet; C8- Straw addition in upland crops; C9- Biochar addition.

Each bar represents a mitigation measure, differentiated by the implementation cost per tonne of $\mathrm{CO}_{2} \mathrm{e}$ reduced (height of bar), and the quantity of emissions $\mathrm{CO}_{2} \mathrm{e}$ reduced (width of bar). Measures below the $\mathrm{x}$ axis are cost negative - i.e. removing emissions and saving money. 
Appendix A Past and Predicted future agriculture activities

Table A.6 Past and predicted future agriculture activities (crops)

\begin{tabular}{|c|c|c|c|c|c|c|c|c|c|c|c|c|c|}
\hline \multirow[b]{2}{*}{ Crops } & \multicolumn{3}{|c|}{ Cropping area(kha) } & \multicolumn{3}{|c|}{ Production $(\mathrm{kt})$} & \multicolumn{3}{|c|}{ Yield $\left(\mathrm{t} \mathrm{ha}^{-1}\right)$} & \multicolumn{4}{|c|}{ Price $\left(¥ \mathrm{~kg}^{-1}\right)$} \\
\hline & 2010 & $2020^{*}$ & $\begin{array}{l}\text { Annual } \\
\text { change }\end{array}$ & 2010 & $2020^{*}$ & $\begin{array}{l}\text { Annual } \\
\text { change }\end{array}$ & 2010 & $2020^{*}$ & $\begin{array}{l}\text { Annual } \\
\text { change }\end{array}$ & 2010 & 2020 & $\begin{array}{c}\text { Original } \\
\text { CAPSiM } \\
\text { annual change }\end{array}$ & $\begin{array}{c}\text { Adjusted by } \\
\text { inflation } \\
(+2 \%)^{\dagger}\end{array}$ \\
\hline Rice & 29,873 & 25,612 & $-1.5 \%$ & 195,761 & 176,823 & $-1.0 \%$ & 6.55 & 6.90 & $0.5 \%$ & 2.36 & 3.02 & $0.7 \%$ & $2.5 \%$ \\
\hline Wheat & 24,257 & 22,099 & $-0.9 \%$ & 115,181 & 113,260 & $-0.2 \%$ & 4.75 & 5.13 & $0.8 \%$ & 1.98 & 2.46 & $0.4 \%$ & $2.2 \%$ \\
\hline Maize & 32,500 & 35,361 & $0.8 \%$ & 177,245 & 221,882 & $2.3 \%$ & 5.45 & 6.27 & $1.4 \%$ & 1.87 & 3.13 & $3.5 \%$ & $5.3 \%$ \\
\hline Soybean & 8,516 & 8,223 & $-0.3 \%$ & 15,083 & 16,549 & $0.9 \%$ & 1.77 & 2.01 & $1.3 \%$ & 3.87 & 5.46 & $1.7 \%$ & $3.5 \%$ \\
\hline Cotton & 4,849 & 5,168 & $0.6 \%$ & 5,961 & 7,503 & $2.3 \%$ & 1.23 & 1.45 & $1.7 \%$ & 24.77 & 26.28 & $-1.1 \%$ & $0.6 \%$ \\
\hline Oils & 13,890 & 14,613 & $0.5 \%$ & 7,106 & 8,757 & $2.1 \%$ & 0.51 & 0.60 & $1.6 \%$ & 5.25 & 8.50 & $3.1 \%$ & $4.9 \%$ \\
\hline Sugar & 1,905 & 1,837 & $-0.4 \%$ & 14,199 & 15,297 & $0.7 \%$ & 7.45 & 8.33 & $1.1 \%$ & 0.45 & 0.68 & $2.3 \%$ & $4.1 \%$ \\
\hline Total vegetable & 19,000 & 19,040 & $0.0 \%$ & 650,994 & 785,748 & $1.9 \%$ & 34.26 & 41.27 & $1.9 \%$ & 1.56 & 2.21 & $1.7 \%$ & $3.5 \%$ \\
\hline $\begin{array}{l}\text { Greenhouse } \\
\text { vegetable }\end{array}$ & 3,553 & 3,560 & $0.0 \%$ & 162,749 & 196,437 & $1.9 \%$ & 45.81 & 55.17 & $1.9 \%$ & 1.98 & 2.81 & $1.7 \%$ & $3.5 \%$ \\
\hline Openfield vegetable & 15,447 & 15,479 & $0.0 \%$ & 488,246 & 589,311 & $1.9 \%$ & 31.61 & 38.07 & $1.9 \%$ & 1.42 & 2.01 & $1.7 \%$ & $3.5 \%$ \\
\hline Fruit & 11,544 & 11,668 & $0.1 \%$ & 128,652 & 176,712 & $3.2 \%$ & 11.14 & 15.14 & $3.1 \%$ & 3.54 & 4.72 & $0.9 \%$ & $2.9 \%$ \\
\hline
\end{tabular}

*Future cropping area, production, yield and agricultural price change (with variations among years) were direct modeled results of CAPSiM.

$\dagger$ Since inflation is not an element considered in the CAPSiM model, here we adjusted price variation rate by assumed annual inflation at $+2 \%$ ( $+2.1 \%$ during $2001-2010)$.

* CAPSiM model gives information on total vegetable; here we split into greenhouse and openfield vegetables to facilitate subsequent mitigation potential analysis. We assume that greenhouse vegetable accounts for $18.7 \%$ and $25 \%$ of total vegetable cropping area and production, respectively, from 2005 to 2020 (Wang et al., 2010 ). 
Table A.7 Past and predicted meat production and livestock numbers

\begin{tabular}{|c|c|c|c|c|c|c|}
\hline \multicolumn{3}{|c|}{$\begin{array}{l}\text { CAPSiM results on } \\
\text { production }(\mathrm{kt})^{*}\end{array}$} & & \multicolumn{3}{|c|}{ Livestock population (1000 heads) ${ }^{\dagger}$} \\
\hline & 2010 & 2020 & & & 2010 & 2020 \\
\hline Beef & 4,571 & 7,330 & \multirow{6}{*}{$\begin{array}{c}\text { Stock } \\
\text { population }\end{array}$} & Non-dairy cattle & 92,063 & 147,617 \\
\hline Milk & 37,480 & 60,952 & & Milk cows & 14,201 & 23,095 \\
\hline \multirow[t]{4}{*}{ Mutton } & 3,390 & 4,921 & & Sheep+goats & 280,879 & 407,711 \\
\hline & & & & Horses & 6,771 & 6,771 \\
\hline & & & & Asses & 6,397 & 6,397 \\
\hline & & & & Mules & 2,697 & 2,697 \\
\hline Pork & 43,877 & 56,137 & \multirow{4}{*}{$\begin{array}{l}\text { Slaughter } \\
\text { population }\end{array}$} & Pigs & 666,864 & 853,203 \\
\hline Poultry & 14,905 & 20,607 & & Chicken & & \\
\hline \multirow[t]{2}{*}{ Eggs } & 19,015 & 23,201 & & (Poultry: hens $=1: 1$ ) & $11,005,780$ & $14,297,441$ \\
\hline & & & & rabbits & 454,455 & 740,259 \\
\hline
\end{tabular}

* Data used in the CAPSiM model are not completely in consistent with those in the China Rural Statistic Yearbooks. Population of horses, asses and mules is assumed to be stable according to historical trends and rabbit population shall grow by $5 \%$ annually.

${ }^{\dagger}$ Predicted livestock numbers (from 2011 onwards) are calculated using relevant product growth rates assuming per head production remain constant to 2020 as in 2010.

* Use slaughter population for pigs, chickens and rabbits since they are alive for only part of a complete year before slaughtering. 
Table A.8 Total $\mathrm{N}$ fertilizer use in agriculture and national average application rate

\begin{tabular}{|c|c|c|c|c|}
\hline & 2005 & 2010 & 2015 & 2020 \\
\hline National total $\mathrm{N}$ fertilizer use $(\mathrm{kt})$ & 29,761 & 32,599 & 35,172 & 36,967 \\
\hline $\mathrm{N}$ fertilizer rate $\left(\mathrm{kg} \mathrm{ha}^{-1}\right)$ & $2005^{*}$ & $2010^{*}$ & $2015^{\dagger}$ & $2020^{\dagger}$ \\
\hline Rice & 190 & 187 & 182 & 177 \\
\hline Wheat & 189 & 209 & 219 & 238 \\
\hline Maize & 186 & 208 & 211 & 221 \\
\hline Soybean & 49 & 54 & 53 & 53 \\
\hline Cotton & 235 & 246 & 237 & 237 \\
\hline Oils & 116 & 125 & 123 & 123 \\
\hline Sugar & 256 & 347 & 322 & 322 \\
\hline Total vegetable & 298 & 368 & 335 & 336 \\
\hline Greenhouse vegetable & 581 & 719 & 655 & 656 \\
\hline Openfield vegetable & 232 & 288 & 262 & 262 \\
\hline Fruit $^{\S}$ & 357 & 492 & 507 & 565 \\
\hline$\%$ of total $\mathrm{N}$ consumption & 2005 & 2010 & 2015 & 2020 \\
\hline Rice & $18.4 \%$ & $17.2 \%$ & $13.8 \%$ & $12.3 \%$ \\
\hline Wheat & $14.5 \%$ & $15.6 \%$ & $14.2 \%$ & $14.2 \%$ \\
\hline Maize & $16.5 \%$ & $20.7 \%$ & $20.4 \%$ & $21.2 \%$ \\
\hline Soybean & $1.6 \%$ & $1.4 \%$ & $1.3 \%$ & $1.2 \%$ \\
\hline Cotton & $4.0 \%$ & $3.7 \%$ & $3.4 \%$ & $3.3 \%$ \\
\hline Oils & $5.6 \%$ & $5.3 \%$ & $5.0 \%$ & $4.9 \%$ \\
\hline Sugar & $1.3 \%$ & $2.0 \%$ & $1.6 \%$ & $1.6 \%$ \\
\hline Total vegetable & $17.7 \%$ & $21.5 \%$ & $18.2 \%$ & $17.3 \%$ \\
\hline Fruit & $11.4 \%$ & $16.5 \%$ & $15.9 \%$ & $16.8 \%$ \\
\hline
\end{tabular}

${ }^{*} \mathrm{~N}$ fertilizer application rates of different crops were collected from the China Agricultural Products Cost-Benefit Yearbooks (NDRC, 1998-2013), and we adopted N fraction of $30 \%$ in the reported compound and mixed fertilizers (Sun and Huang, 2012).

${ }^{\dagger}$ Extrapolation of future $\mathrm{N}$ fertilizer rates were based on 2005-2011 data for rice, wheat and maize, 1998-2011 data for fruits and vegetables, and average of 2006-2011 data for other crops.

$\$$ According to survey results (Chadwick et al., 2013; Zhang et al., 2013), N application rate for greenhouse vegetables is generally about 2-3 times as that for openfield vegetables (here we assume 2.5 times).

${ }^{\S}$ Due to lack of data for other fruits, we used average fertilizer rate of apple, mandarin and orange to represent general fruits. 


\section{Appendix B Projections of $\mathrm{N}_{2} \mathrm{O}$ emissions from Chinese croplands under the BAU scenario}

We followed IPCC 2006 Guideline to estimate baseline $\mathrm{N}_{2} \mathrm{O}$ emissions related to crops and soils in China in 2020. We considered both direct and indirect $\mathrm{N}_{2} \mathrm{O}$ emissions from the three major $\mathrm{N}$ input sources-synthetic fertilizers, organic manure and crop residues, which are consistent with the National GHG Inventories (NCCC, 2004, 2012). The calculation was conducted following Eq. (B.1).

$$
\begin{aligned}
& \text { Emissions }_{N_{2} O}=N_{2} O-N \square E F=N_{2} O-N \square\left(E F_{\text {direct }}+E F_{\text {indirect }}\right) \\
& N_{2} O-N=F_{S N}+F_{A W}+F_{C R} \\
& E F_{\text {direct }}=N_{2} O \square E F_{1} \square 44 / 28 \square G W P_{N_{2} O} O \\
& E F_{\text {indirect }}=\left(F _ { G r a c } [ E F _ { 4 } + F r a c _ { L E A C H } \square E F _ { 5 } ) \left[44 / 28 \llbracket G W P_{N_{2} O} O\right.\right.
\end{aligned}
$$

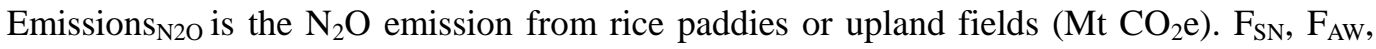
$\mathrm{F}_{\mathrm{CR}}$ represent $\mathrm{N}$ inputs from synthetic fertilizers, animal manure and crop residues $(\mathrm{Mt} N)$. $\mathrm{EF}_{1}$, $\mathrm{EF}_{4}, \mathrm{EF}_{5}$ are the emission factors for $\mathrm{N}_{2} \mathrm{O}$ emissions from $\mathrm{N}$ inputs, $\mathrm{N}$ volatilization, and $\mathrm{N}$ leaching and runoff, respectively. GWP $\mathrm{N}_{2} \mathrm{O}$ is the direct Global Warming Potential (GWP) of $\mathrm{N}_{2} \mathrm{O}$ at the 100yr horizon, 298. Frac $\mathrm{GAS}_{\mathrm{GS}}$ and $\mathrm{Frac}_{\mathrm{LEACH}}$ are fractions of $\mathrm{N}$ that are lost through atmospheric deposition of $\mathrm{N}$ volatilised and leaching or runoff. Refer to Table B.1 for results of $\mathrm{EF}_{\text {direct }}$ and $\mathrm{EF}_{\text {indirect }}$ and selection of $\mathrm{EF}_{1}, \mathrm{Frac}_{\mathrm{GAS}}, \mathrm{EF}_{4}, \mathrm{Frac}_{\mathrm{LEACH}}$ and $\mathrm{EF}_{5}$.

$\mathrm{F}_{\mathrm{SN}}$ for rice paddies were estimated by multiplying rice $\mathrm{N}$ fertilizer rate (Table A.8) by rice cropping area ( 


\section{Appendix A Past and Predicted future agriculture activities}

Table A.6), and we got $\mathrm{F}_{\mathrm{SN}}$ for upland crops by subtracting $\mathrm{F}_{\mathrm{SN}}$-rice paddies from total synthetic $\mathrm{N}$ fertilizer consumption.

$\mathrm{F}_{\mathrm{AW}}$ was estimated following Eq. (B.2).

$$
\begin{aligned}
& F_{A W}=\sum_{T} N_{T} \sqsubset\left(1-\operatorname{Frac}_{\left.\operatorname{Grazing}_{(T)}\right)}\right) \operatorname{Nex}_{T} \square\left(1-\operatorname{Frac}_{\text {Loss }(T)}\right) \\
& \operatorname{Nex}_{T}=N_{\text {rate }(T)}\left[\frac{T A M_{T}}{1000}\right] B 65 \\
& N_{T}=\text { Days_alive }_{T}\left[\frac{N_{S(T)}}{365} \text { if Days_alive } \text { D }_{T}<365\right.
\end{aligned}
$$

$\mathrm{N}_{\mathrm{T}}$ is annual average population of livestock $\mathrm{T}$ (use stock number if average breeding days is more than a complete year). $\operatorname{Frac}_{\mathrm{Grazing}(\mathrm{T})}$ is the fraction of grazing population of livestock $\mathrm{T}(\%)$. $\mathrm{Nex}_{\mathrm{T}}$ is annual $\mathrm{N}$ excretion for livestock category $\mathrm{T}\left(\mathrm{kg} \mathrm{N}\right.$ animal $\left.^{-1} \mathrm{yr}^{-1}\right)$. $\operatorname{Frac}_{\mathrm{Loss}(\mathrm{T})}$ is the amount of managed manure nitrogen for livestock category $\mathrm{T}$ that is lost in the manure management system $\mathrm{S}(\%) . \mathrm{N}_{\text {rate(T) }}$ is the default $\mathrm{N}$ excretion rate $\left(\mathrm{kgN}\left(1000 \mathrm{~kg}\right.\right.$ animal mass ${ }^{-1}$ day $\left.^{-1}\right)$. $\mathrm{TAM}_{\mathrm{T}}$ denotes typical animal mass for livestock category $\mathrm{T}\left(\mathrm{kg}\right.$ animal $\left.^{-1}\right)$. Days_alive $\mathrm{T}_{\mathrm{T}}$ is the average growth days before slaughtering. $\mathrm{N}_{\mathrm{S}(\mathrm{T})}$ is the slaughtered number of livestock $\mathrm{T}$ in average. Selected default values for parameters in Eq. B.2 are summarized in

Table B.2. According to survey results (Huang and Tang, 2010; Zhang et al., 2013), we assumed that $10 \%$ of animal manure were applied to rice paddies and the rest $90 \%$ to upland fields.

$\mathrm{F}_{\mathrm{CR}}$ was estimated following Eq. (B.3).

$$
\begin{aligned}
& F_{C R}=\sum_{i} F_{C R-A G(i)}+F_{C R-B G(i)} \\
& =\sum_{i} P d t_{i} \square R_{S T-G R(i)} \llbracket N_{i} \llbracket\left(R_{S R(i)}+R_{B G-A G(i)}\right)
\end{aligned}
$$

Where $\mathrm{F}_{\mathrm{CR}-\mathrm{AG}(\mathrm{i})}$ and $\mathrm{F}_{\mathrm{CR}-\mathrm{BG}(\mathrm{i})}$ represent $\mathrm{N}$ input from aboveground and belowground crop residues (Mt N). i denotes the crop type. Pdt is the annual crop production (Table A.1). $\mathrm{R}_{\mathrm{ST}-\mathrm{GR}}$ is the ratio of straw to grain in terms of dray matter. $\mathrm{N}$ is residue $\mathrm{N}$ content $\left(\mathrm{g} \mathrm{kg}^{-1}\right) . \mathrm{R}_{\mathrm{SR}}$ is the

\begin{tabular}{|c|c|c|c|c|c|c|c|c|c|}
\hline \multirow[b]{2}{*}{$\begin{array}{l}\text { Data } \\
\text { sources }\end{array}$} & \multirow[b]{2}{*}{$\begin{array}{c}\text { Crop } \\
\text { systems }\end{array}$} & \multicolumn{3}{|c|}{ Direct $\mathrm{N}_{2} \mathrm{O}^{*}$} & \multicolumn{4}{|c|}{ Indirect $\mathrm{N}_{2} \mathrm{O}^{\dagger}$} & \multirow{2}{*}{$\begin{array}{l}\text { Total EF } \\
\left(\mathrm{tCO}_{2} \mathrm{e}\right. \\
\left.\mathrm{tN}^{-1}\right)\end{array}$} \\
\hline & & $\mathrm{EF}_{1}$ & $\begin{array}{c}\mathrm{EF}\left(\mathrm{tCO}_{2} \mathrm{e}\right. \\
\left.\mathrm{tN}^{-1}\right)\end{array}$ & $\begin{array}{c}\operatorname{Frac}_{\mathrm{GAS}} \\
(\%)\end{array}$ & $\mathrm{EF}_{4}$ & $\begin{array}{c}\text { Frac }_{\text {LEACH }} \\
(\%)\end{array}$ & $\mathrm{EF}_{5}$ & $\begin{array}{c}\mathrm{EF}\left(\mathrm{tCO}_{2} \mathrm{e}\right. \\
\left.\mathrm{tN}^{-1}\right)\end{array}$ & \\
\hline China & Rice paddy & 0.41 & 1.92 & 17.9 & 0.01 & 1.4 & 0.0075 & 0.89 & 2.81 \\
\hline specific & Upland field & 1.05 & 4.92 & 12.9 & 0.01 & 9.8 & 0.0075 & 0.95 & 5.87 \\
\hline IPCC & Rice paddy & 0.30 & 1.40 & 10.0 & 0.01 & 30.0 & 0.0075 & 1.52 & 2.93 \\
\hline
\end{tabular}
proportion of above-ground straw returned to land (\%). $\mathrm{R}_{\mathrm{BG}-\mathrm{AG}}$ is the ratio of below-ground residue weight to above-ground plant weight. Values of parameters in Eq. S3 were mainly obtained from Gao et al. (2011), which are summarized in Table B.3.

Table B.1 GHG emission factors for $\mathrm{N}$ inputs to China's croplands 


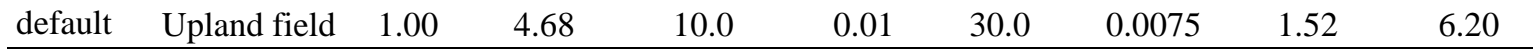

* Direct $\mathrm{N}_{2} \mathrm{O}$ emission factors are from a study by Gao et al. (2012) based on $456 \mathrm{~N}_{2} \mathrm{O}$ emission measurements in China.

${ }^{\dagger}$ Indirect $\mathrm{N}_{2} \mathrm{O}$ emission factors are obtained from Zhang et al. (2013) based on $397 \mathrm{~N}_{2} \mathrm{O}$ emission measurements in China.

Table B.2 Selected values for estimating $\mathrm{N}$ input to croplands from animal manure

\begin{tabular}{lccccccccc}
\hline & $\begin{array}{c}\text { Non-dairy } \\
\text { cattle }\end{array}$ & $\begin{array}{c}\text { Milk } \\
\text { cows }\end{array}$ & $\begin{array}{c}\text { Sheep+ } \\
\text { goats }\end{array}$ & Horses & Asses & Mules & Pigs & Chicken & Rabbits \\
\hline Frac $_{\text {Grazing }}$ & $17 \%$ & & $35 \%$ & & & & & & \\
$\mathrm{~N}_{\text {rate }}$ & 0.34 & 0.47 & 0.27 & 0.46 & 0.46 & 0.46 & 0.50 & 0.82 & \\
$\mathrm{TAM}$ & 319 & 350 & 29 & 238 & 130 & 130 & 28 & 2 & 0 \\
$\mathrm{Nex}$ & 39.6 & 60.0 & 2.9 & 40.0 & 21.8 & 21.8 & 5.1 & 0.5 & 8.1 \\
Frac $_{\text {Loss }}$ & $40 \%$ & $40 \%$ & $67 \%$ & $50 \%$ & $50 \%$ & $50 \%$ & $35 \%$ & $50 \%$ & $50 \%$ \\
Days_alive $^{\dagger}$ & & & & & & & 158 & 180 & 105 \\
\hline
\end{tabular}

* Proportion of grazed cattle and sheep are summarized from relevant livestock numbers in grazing areas and half-grazing areas (MOA, 2005-2012a)

$\dagger$ Average growth days of pigs, chicken and rabbits were cited from China Livestock Yearbook.

Days_alive of chicken are weighted number of poultry (65 days) and hens (352 days).

$\underline{\text { Table B.3 Selected values for estimating } \mathrm{N} \text { input to croplands from crop residues }}$

\begin{tabular}{|c|c|c|c|c|c|c|c|}
\hline & \multirow[t]{2}{*}{$\mathrm{R}_{\mathrm{ST}-\mathrm{GR}}$} & \multirow{2}{*}{$\begin{array}{c}\mathrm{N} \\
\mathrm{g} \mathrm{kg}^{-1}\end{array}$} & \multicolumn{4}{|c|}{$\mathrm{R}_{\mathrm{SR}}{ }^{*}$} & \multirow[t]{2}{*}{$\mathrm{R}_{\mathrm{BG}-\mathrm{AG}}$} \\
\hline & & & 2005 & 2010 & 2015 & 2020 & \\
\hline Rice & 0.9 & 9.1 & $29 \%$ & $34 \%$ & $35 \%$ & $36 \%$ & 0.13 \\
\hline Wheat & 1.1 & 6.5 & $42 \%$ & $49 \%$ & $51 \%$ & $52 \%$ & 0.17 \\
\hline Maize & 1.2 & 9.2 & $26 \%$ & $30 \%$ & $31 \%$ & $32 \%$ & 0.17 \\
\hline Potato & 0.5 & 25.0 & $18 \%$ & $21 \%$ & $22 \%$ & $22 \%$ & 0.05 \\
\hline Soybean & 1.0 & 21.0 & $45 \%$ & $52 \%$ & $53 \%$ & $55 \%$ & 0.13 \\
\hline Cotton & 3.0 & 12.4 & $12 \%$ & $14 \%$ & $15 \%$ & $15 \%$ & 0.20 \\
\hline Oils & 1.7 & 13.5 & $17 \%$ & $20 \%$ & $21 \%$ & $22 \%$ & 0.17 \\
\hline Vegetable & 0.5 & 2.5 & $5 \%$ & $6 \%$ & $6 \%$ & $6 \%$ & 0.25 \\
\hline
\end{tabular}

* Proportions of above-ground straw returned to land were cited from Gao et al. (2009) and 3\% annual growth rate was employed for straw incorporation rate in the future. 


\section{Appendix C Estimation of abatement rates of mitigation measures}

A meta-analysis (Nayak et al., 2013) was conducted to estimate the average technical abatement rates of mitigation measures specific to China. We made some adjustments of original meta-analysis results in this study to better accommodate actual situations and partially internalize measure interactions. Table C.1 presents the direct $\mathrm{N}$ rate decrease induced abatement potential of measures $\mathrm{C} 1, \mathrm{C} 2, \mathrm{C} 3$ and $\mathrm{C} 4$, which were estimated employing emission factors (Table B.1) and the relationship between $\mathrm{N}$ fertilizer reduction and $\mathrm{N}_{2} \mathrm{O}$ emissions reduction drawn from site experiments (database from Nayak et al., 2013) shown in Fig. C.1. Due to lack of emission data from fruit, we used emission data from vegetable to estimate mitigation potential for fruits. We concluded from relevant literature (Ge, 2009; Jiao et al., 2010) that overuse of $\mathrm{N}$ fertilizer is phenomenal in nearly all greenhouse vegetable fields, and we assumed that about $50 \%$ of openfield vegetable areas receive $40 \%$ excessive $\mathrm{N}$ fertilizers than crop demands. Regarding orchards, survey results (Lu et al., 2008; Zhang et al., 2012) indicate that average $\mathrm{N}$ inputs rates were over 2.5 fold higher than fruit requirement in about $70 \%$ of orchards. Drip-irrigation has been proven to be a prominent technology in improving cotton yields and reducing fertilizer and irrigation inputs, and was therefore considered the dominant mitigation measure in cotton production. Since both high-efficiency irrigation systems and replacement of ammonia-based fertilizers with nitrate-based fertilizers are able to lower $\mathrm{N}_{2} \mathrm{O}$ emissions by at least $50 \%$ (SAIN, 2012), i.e. halving emission factors, this part of mitigation potential was also quantified in addition to emission reduction related to direct $\mathrm{N}$ rate decrease.

The abatement rate of measure $\mathrm{C} 3$ was the integrated effects of shifting from mid-season drainage (F-D-F) to intermittent irrigation (F-D-F-M) regime $\left(1.256 \mathrm{CO}_{2} \mathrm{e} \mathrm{ha}{ }^{-1}\right)$ and reduced $\mathrm{N}$ fertilizer rate $\left(0.081 \mathrm{CO}_{2} \mathrm{e} \mathrm{ha}{ }^{-1}\right)$.

Due to limited dataset in China specific meta-analysis, estimates of abatement rate from using enhanced efficiency fertilizers were based on the global meta analysis results (Akiyama et al., 2010) suggesting NIs can reduce $\mathrm{N}_{2} \mathrm{O}$ by $34 \%$ in upland fields and $30 \%$ in rice paddies on average, compared with those of conventional fertilizers.

Meta analysis mitigation potential of adding organic manure to croplands were discounted because organic manure have already been applied to croplands in practice opposed to the zero organic manure assumption under controlled experiments. According to Zhang et al. (2013) and Huang et al. (2010), organic manure supplied about 9\%-12\% of total $\mathrm{N}$ input for grain crops. Chadwick et al. (2013) indicated that for greenhouse vegetables $>50 \%$ of the nutrients supply come from the manures, for open field vegetables and fruit, manure supply ca. $33 \%$ and $20 \%$ of the total $\mathrm{N}$ nutrients, respectively. Typical fertilization recommendations suggest organic manure providing $30 \%$ of $\mathrm{N}$ nutrients to crops and $50 \%$ to fruits and vegetables. The average abatement rate for wheat and maize were extended to other upland crops. Net emissions of adding manure to rice paddy were estimated under intermittent irrigation regime. 
Meta analysis results were directly used for conservation tillage and straw returning.

Regarding biochar addition, positive effects of biochar on $\mathrm{C}$ sequestration were reported in literature but not included here giving uncertainty considerations constrained by limited and short-term studies. Mitigation potential from this measure sourced from decreased $\mathrm{N}_{2} \mathrm{O}$ emissions in upland crops by $40 \%$ and rice paddies by $50 \%$ by global meta-analysis (Pan, 2012).

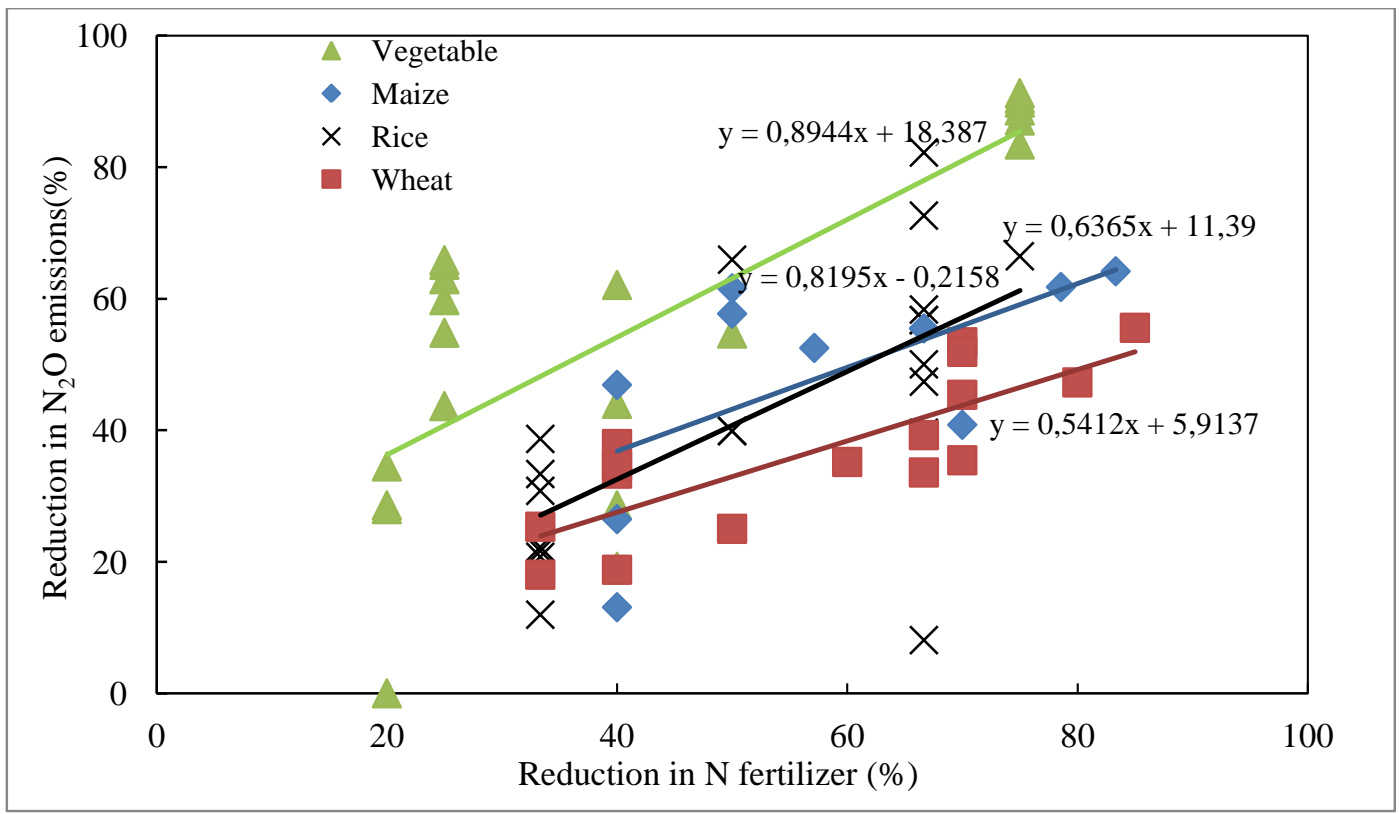

Fig. C.1 Relationship between reduction percentages of $\mathrm{N}$ fertilizers and $\mathrm{N}_{2} \mathrm{O}$ emissions. The equation for rice is $\mathrm{y}=0.8195 \mathrm{x}-0.2158$, for wheat is $\mathrm{y}=0.5412 \mathrm{x}+5.9137$, for maize is $\mathrm{y}=0.6365 \mathrm{x}+11.39$, and for vegetable is $\mathrm{y}=0.8944+18.387$. 
Table C.1 Mitigation potential estimates of abatement measure $\mathrm{C} 1$, measure $\mathrm{C} 2$ and measure $\mathrm{C} 4$

\begin{tabular}{|c|c|c|c|c|c|c|c|c|c|c|c|c|c|c|c|}
\hline \multirow[b]{2}{*}{ Provinces } & \multicolumn{6}{|c|}{ BAU scenario $^{*}$} & \multicolumn{4}{|c|}{ Mitigation measure C1 } & \multicolumn{4}{|c|}{ Mitigation measure C2 } & \multirow[b]{2}{*}{$\begin{array}{c}\mathrm{N} \text { rate } \\
\text { objective } \\
\left(\mathrm{kg} \mathrm{ha}^{-1}\right)\end{array}$} \\
\hline & $\begin{array}{l}\text { N rate } \\
\text { 2008-2010 } \\
\text { average } \\
\quad\left(\mathrm{kg} \mathrm{ha}^{-1}\right.\end{array}$ & $\begin{array}{r}2020 \\
\end{array}$ & $\begin{array}{c}\text { Yield } \\
\text { 2008-2010 } \\
\text { average } \\
\left(\mathrm{t} \mathrm{ha}^{-1}\right.\end{array}$ & 2020 & $\begin{array}{c}\mathrm{PFP}_{\mathrm{N}} \\
\text { 2008-2010 } \\
\text { average } \\
\left(\mathrm{kg} \mathrm{kg}^{-}\right.\end{array}$ & 2020 & $\begin{array}{c}\text { Target } \\
\operatorname{PFP}_{\mathrm{N}}(70 \% \text { of } \\
\text { optimum) } \\
\left(\mathrm{kg} \mathrm{kg}^{-1)}\right.\end{array}$ & $\begin{array}{l}\mathrm{N} \text { rate } \\
\text { reduce }\end{array}$ & $\begin{array}{l}\mathrm{N}_{2} \mathrm{O} \\
\text { emission } \\
\text { reduction } \\
(\%)\end{array}$ & $\begin{array}{c}\text { Mitigation } \\
\text { potential } \\
\left(\mathrm{ktCO}_{2} \mathrm{e}\right)\end{array}$ & $\begin{array}{l}\text { Optimal } \\
\operatorname{PFP}_{\mathrm{N}}^{\dagger} \\
\left(\mathrm{kg} \mathrm{kg}^{-1}\right)\end{array}$ & $\begin{array}{c}\text { Yield } \\
\text { increase } \\
\text { by } \\
\left(\mathrm{t} \mathrm{ha}^{-1}\right)\end{array}$ & $\begin{array}{l}\mathrm{N} \\
\text { reduce } \\
\text { quantity } \\
(\mathrm{kt})\end{array}$ & $\begin{array}{l}\text { Mitigation } \\
\text { potential } \\
\left(\mathrm{ktCO}_{2} \mathrm{e}\right)\end{array}$ & \\
\hline Rice & & & & & & & & & & & & $5 \%$ & & & \\
\hline Tianjin & 259 & 246 & 7.04 & 7.40 & 28.3 & 30.0 & 35.0 & 14.2 & 11.4 & 1.1 & 50.0 & 7.8 & 0.8 & 1.7 & 155 \\
\hline Hebei & 344 & 328 & 6.79 & 7.14 & 18.7 & 21.8 & 35.0 & 37.8 & 30.7 & 20.1 & 50.0 & 7.5 & 3.8 & 8.8 & 150 \\
\hline Inner mengolia & 221 & 211 & 7.23 & 7.60 & 33.4 & 36.1 & 35.0 & & & & 50.0 & 8.0 & 4.3 & 9.8 & 160 \\
\hline Liaoning & 235 & 224 & 7.38 & 7.76 & 31.4 & 34.6 & 52.5 & 34.0 & 27.6 & 100.0 & 75.0 & 8.1 & 22.5 & 51.9 & 109 \\
\hline Jilin & 170 & 162 & 8.29 & 8.72 & 48.9 & 53.9 & & & & & 75.0 & 9.2 & 22.8 & 52.0 & 122 \\
\hline Heilongjiang & 120 & 114 & 6.47 & 6.80 & 54.0 & 59.5 & & & & & 75.0 & 7.1 & 42.0 & 95.1 & 95 \\
\hline Shanghai & 326 & 311 & 8.28 & 8.71 & 24.8 & 28.0 & 36.1 & 22.5 & 18.2 & 14.9 & 51.6 & 9.1 & 6.0 & 13.8 & 177 \\
\hline Jiangsu & 290 & 277 & 8.03 & 8.45 & 27.7 & 30.5 & 36.1 & 15.4 & 12.4 & 186.7 & 51.6 & 8.9 & 119.9 & 276.1 & 172 \\
\hline Zhejiang & 227 & 217 & 7.06 & 7.42 & 31.1 & 34.3 & 36.1 & 5.1 & 4.0 & 19.5 & 51.6 & 7.8 & 44.0 & 101.3 & 151 \\
\hline Anhui & 205 & 195 & 6.22 & 6.54 & 30.4 & 33.5 & 38.9 & 13.9 & 11.2 & 118.9 & 55.6 & 6.9 & 86.1 & 198.4 & 123 \\
\hline Fujian & 159 & 152 & 5.94 & 6.24 & 37.3 & 41.1 & & & & & 50.5 & 6.6 & 16.3 & 37.0 & 130 \\
\hline Jiangxi & 164 & 156 & 5.71 & 6.00 & 34.9 & 38.5 & & & & & 50.5 & 6.3 & 88.8 & 201.9 & 125 \\
\hline Shandong & 285 & 272 & 8.35 & 8.78 & 29.3 & 32.3 & 35.0 & 7.7 & 6.1 & 5.3 & 50.0 & 9.2 & 7.6 & 17.4 & 184 \\
\hline Henan & 213 & 203 & 7.40 & 7.78 & 34.8 & 38.4 & 35.0 & & & & 50.0 & 8.2 & 20.9 & 47.4 & 163 \\
\hline Hubei & 168 & 160 & 7.73 & 8.12 & 46.1 & 50.9 & & & & & 55.0 & & & & 160 \\
\hline Hunan & 148 & 141 & 6.34 & 6.66 & 42.8 & 47.2 & & & & & 56.5 & 7.0 & 60.5 & 136.4 & 124 \\
\hline Guangdong & 191 & 182 & 5.33 & 5.60 & 28.0 & 30.8 & 35.3 & 12.7 & 10.2 & 88.2 & 50.5 & 5.9 & 71.0 & 163.6 & 117 \\
\hline Guangxi & 196 & 186 & 5.32 & 5.60 & 27.3 & 30.0 & 35.3 & 15.0 & 12.1 & 116.0 & 50.5 & 5.9 & 76.8 & 176.8 & 116 \\
\hline Hainan & 144 & 137 & 4.50 & 4.73 & 31.2 & 34.4 & & & & & 50.5 & 5.0 & 10.7 & 24.5 & 98 \\
\hline Chongqing & 143 & 136 & 7.65 & 8.04 & 53.6 & 59.1 & & & & & 50.0 & & & & 136 \\
\hline Sichuan & 201 & 192 & 7.47 & 7.85 & 37.5 & 41.0 & & & & & 50.0 & 8.2 & 47.0 & 106.1 & 165 \\
\hline Guizhou & 134 & 127 & 6.52 & 6.86 & 48.8 & 53.8 & & & & & 50.5 & & & & 127 \\
\hline Yunnan & 229 & 219 & 6.09 & 6.40 & 26.8 & 29.3 & 35.3 & 17.2 & 13.8 & 75.5 & 50.5 & 6.7 & 42.6 & 98.2 & 133 \\
\hline Shanxi & 180 & 172 & 6.64 & 6.98 & 37.1 & 40.7 & & & & & 50.0 & 7.3 & 2.7 & 6.1 & 147 \\
\hline Ningxia & 283 & 270 & 8.31 & 8.74 & 29.3 & 32.3 & 35.0 & 7.6 & 6.0 & 3.2 & 55.0 & 9.2 & 5.8 & 13.3 & 167 \\
\hline Nation average & 186 & 177 & 6.57 & 6.90 & 23.2 & 38.9 & & 7.3 & & 749.4 & & 7.2 & 803.0 & 1837.6 & 133 \\
\hline
\end{tabular}




\begin{tabular}{|c|c|c|c|c|c|c|c|c|c|c|c|c|c|c|c|}
\hline Wheat & & & & & & & & & & & & $5 \%$ & & & \\
\hline Beijing & 239 & 286 & 4.95 & 5.34 & 20.5 & 18.7 & 24.9 & 24.9 & 19.4 & 18.5 & 35.6 & 5.6 & 3.2 & 10.3 & 158 \\
\hline Tianjin & 233 & 278 & 4.86 & 5.25 & 20.7 & 18.9 & 24.9 & 24.2 & 19.0 & 31.2 & 35.6 & 5.5 & 5.6 & 17.8 & 155 \\
\hline Hebei & 248 & 296 & 5.09 & 5.50 & 20.6 & 18.6 & 24.9 & 25.4 & 19.6 & 754.9 & 35.6 & 5.8 & 129.5 & 411.2 & 162 \\
\hline Shanxi & 163 & 194 & 3.24 & 3.50 & 19.9 & 18.0 & 24.9 & 27.8 & 21.0 & 157.7 & 35.6 & 3.7 & 24.5 & 77.9 & 103 \\
\hline Inner mengolia & 292 & 349 & 3.19 & 3.44 & 10.9 & 9.9 & 14.9 & 33.9 & 24.3 & 235.3 & 21.4 & 3.6 & 28.9 & 91.8 & 169 \\
\hline Heilongjiang & 97 & 115 & 3.67 & 3.96 & 38.4 & 34.4 & & & & & 35.6 & & & & 115 \\
\hline Jiangsu & 238 & 284 & 4.82 & 5.20 & 20.3 & 18.3 & 27.1 & 32.4 & 23.4 & 747.1 & 38.7 & 5.5 & 97.4 & 309.5 & 141 \\
\hline Anhui & 189 & 225 & 5.03 & 5.42 & 26.8 & 24.1 & & & & & 35.6 & 5.7 & 141.1 & 617.3 & 160 \\
\hline Shandong & 206 & 246 & 5.77 & 6.23 & 28.1 & 25.3 & & & & & 35.6 & 6.5 & 203.1 & 923.5 & 184 \\
\hline Henan & 183 & 219 & 5.81 & 6.27 & 32.0 & 28.7 & & & & & 35.6 & 6.6 & 163.3 & 886.4 & 185 \\
\hline Hubei & 161 & 193 & 3.35 & 3.62 & 20.8 & 18.8 & 24.9 & 24.6 & 19.2 & 199.6 & 35.6 & 3.8 & 35.3 & 112.1 & 107 \\
\hline Chongqing & 101 & 120 & 3.07 & 3.31 & 29.0 & 27.5 & & & & & 35.6 & 3.5 & 3.5 & 17.8 & 98 \\
\hline Sichuan & 124 & 148 & 3.34 & 3.60 & 26.9 & 24.3 & & & & & 35.6 & 3.8 & 49.5 & 217.6 & 106 \\
\hline Yunnan & 113 & 135 & 1.72 & 1.86 & 15.1 & 13.8 & 24.9 & 44.6 & 30.1 & 93.5 & 35.6 & 1.9 & 7.8 & 24.7 & 55 \\
\hline Shanxi & 232 & 276 & 3.43 & 3.70 & 14.9 & 13.4 & 24.7 & 45.7 & 30.6 & 523.1 & 35.2 & 3.9 & 41.8 & 132.9 & 110 \\
\hline Gansu & 189 & 226 & 2.84 & 3.07 & 15.0 & 13.6 & 24.7 & 45.0 & 30.2 & 337.5 & 35.2 & 3.2 & 27.7 & 88.1 & 91 \\
\hline Qinghai & 91 & 108 & 3.82 & 4.12 & 44.0 & 38.1 & & & & & 35.2 & & & & 108 \\
\hline Ningxia & 238 & 284 & 3.28 & 3.54 & 13.8 & 12.5 & 24.7 & 49.4 & 32.7 & 105.6 & 35.2 & 3.7 & 7.4 & 23.4 & 105 \\
\hline Xinjiang & 238 & 284 & 5.51 & 5.94 & 23.2 & 20.9 & 24.7 & 15.2 & 14.1 & 217.3 & 35.2 & 6.2 & 58.9 & 187.0 & 177 \\
\hline Nation average & 199 & 238 & 4.75 & 5.13 & 23.9 & 21.5 & & 15.2 & & 3421.4 & & 5.4 & 1030.5 & 4160.9 & 155 \\
\hline Maize & & & & & & & & & & & & $8 \%$ & & & \\
\hline Beijing & 213 & 233 & 5.86 & 6.79 & 25.2 & 29.1 & 32.7 & 11.1 & 18.5 & 42.7 & 46.7 & 7.3 & 8.5 & 31.9 & 157 \\
\hline Tianjin & 201 & 220 & 5.37 & 6.22 & 26.6 & 28.3 & 32.7 & 13.5 & 20.0 & 48.1 & 46.7 & 6.7 & 8.7 & 32.4 & 144 \\
\hline Hebei & 172 & 188 & 5.02 & 5.81 & 29.3 & 30.9 & 32.7 & & & 549.4 & 46.7 & 6.3 & 144.1 & 538.3 & 134 \\
\hline Shanxi & 181 & 198 & 4.80 & 5.56 & 26.6 & 28.1 & 32.7 & 14.2 & 20.4 & 393.5 & 46.7 & 6.0 & 68.6 & 256.3 & 128 \\
\hline Inner mengolia & 214 & 235 & 5.80 & 6.71 & 27.0 & 28.6 & 32.7 & 12.6 & 19.4 & 736.4 & 46.7 & 7.2 & 137.7 & 514.3 & 155 \\
\hline Liaoning & 198 & 216 & 5.57 & 6.44 & 28.2 & 29.8 & 33.7 & 11.6 & 18.8 & 535.9 & 48.1 & 7.0 & 104.9 & 391.8 & 145 \\
\hline Jilin & 178 & 194 & 6.61 & 7.65 & 37.3 & 39.4 & & & & & 48.1 & 8.3 & 76.5 & 724.2 & 172 \\
\hline Heilongjiang & 136 & 149 & 5.06 & 5.85 & 37.1 & 39.2 & & & & & 48.1 & 6.3 & 80.7 & 753.3 & 131 \\
\hline Jiangsu & 237 & 259 & 5.30 & 6.14 & 22.5 & 23.7 & 32.6 & 27.5 & 28.9 & 199.9 & 46.6 & 6.6 & 20.9 & 77.9 & 142 \\
\hline Anhui & 211 & 230 & 4.11 & 4.76 & 19.6 & 20.7 & 32.6 & 36.7 & 34.7 & 390.3 & 46.6 & 5.1 & 29.6 & 110.5 & 110 \\
\hline Shandong & 215 & 235 & 6.56 & 7.60 & 30.7 & 32.3 & & & & & 46.6 & 8.2 & 195.9 & 1251.9 & 176 \\
\hline Henan & 183 & 200 & 5.64 & 6.53 & 30.8 & 32.6 & & & & & 46.6 & 7.0 & 160.3 & 1037.3 & 151 \\
\hline
\end{tabular}




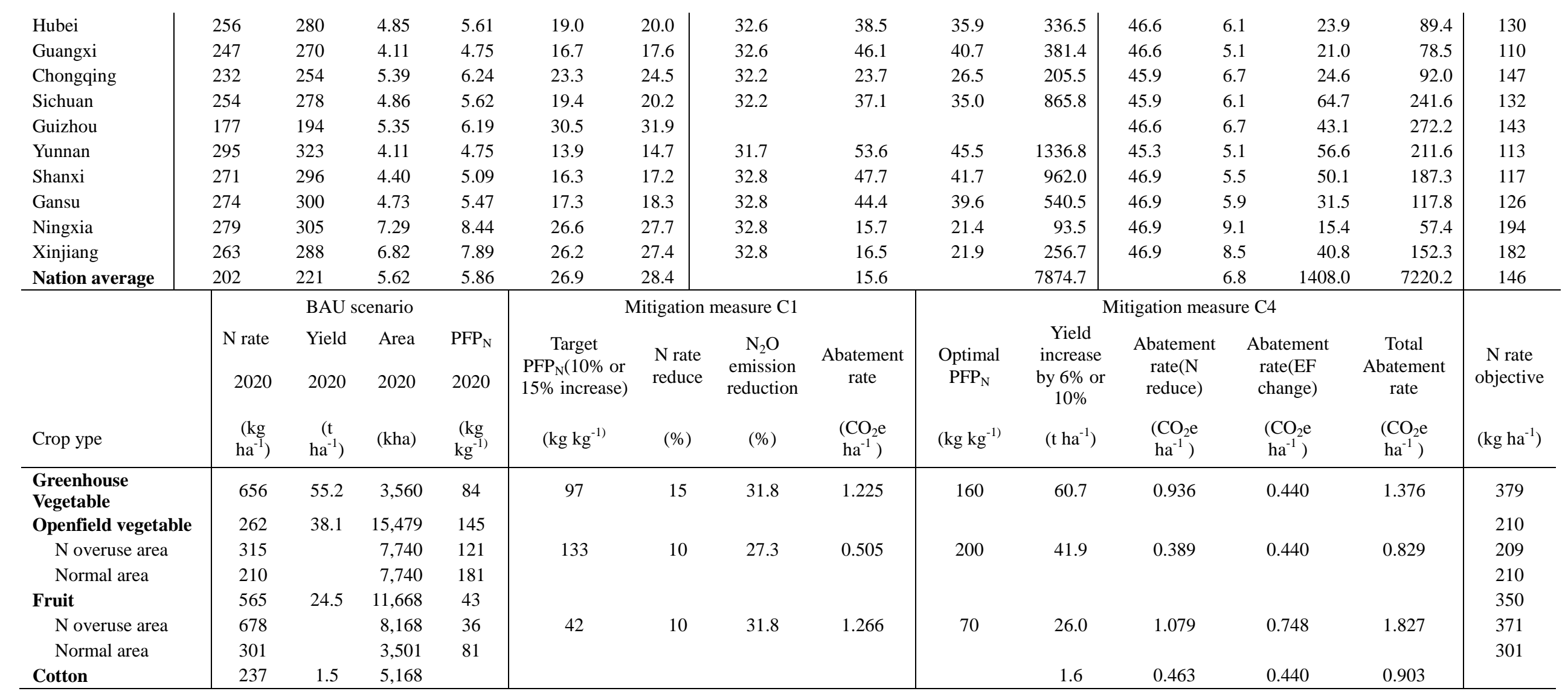

*Baseyear data (average of 2008-2010) were obtained from the China Agricultural Products Cost-Benefit Data (N rate) and the China Rural Statistical Yearbooks (Yield), and future $\mathrm{N}$ rates and yields at provincial level were estimated applying the national average changing rate (Table A.1).

${ }^{\dagger}$ Average optimal PFP $_{\mathrm{N}}$ were derived from recommended $\mathrm{N}$ fertilizer application rates under certain level of yields in various cropping regions (Zhang et al., 2009). 


\section{Appendix D Mitigation measure cost and adoption}

Table D.1 Explication of and references for measure implementation cost estimation

\begin{tabular}{|c|c|}
\hline Measure No. & Explications \\
\hline $\mathrm{C} 1$ & Reductions in $\mathrm{N}$ rates were based on those in target regions (see Table C.1 measure $\mathrm{C} 1$ ), which are higher than national average. \\
\hline $\mathrm{C} 2$ & $\begin{array}{l}\text { More labor inputs for wheat additional topdressing. } \\
\text { Increased machine inputs for maize fertilizer deep placement. }\end{array}$ \\
\hline $\mathrm{C} 3$ & More labor inputs for additional topdressing; irrigation costs saved due to improved irrigation regime. \\
\hline $\mathrm{C} 4$ & $\begin{array}{l}\text { Reductions in } \mathrm{N} \text { fertilizer rates were based on those rates in target regions (see Table C. } 1 \text { measure C4). Use Calcium Ammonium Nitrate } \\
\text { (total nurient } \geq 34 \% \text {, total } \mathrm{N}=26 \% \text { ) to represent nitrate-based fertilizers, with application rate stands at } 450 \mathrm{~kg} / \mathrm{ha} \text { for vegetable and cotton } \\
\text { and } 750 \mathrm{~kg} / \mathrm{ha} \text { for fruit. High-efficient irrigation systems allow for labor savings in vegetable and cotton fields; more labors are required } \\
\text { for fruit fertilizer split application. Subsurface drip irrigation system costs compromise } ¥ 15000 \text { initial investment and installation cost } \\
\text { (lifespan=10years) per hectare and annual maintenance and renewal cost of smaller diameter polytube at ¥1500/ha and film input at } \\
¥ 1000 / \mathrm{ha} \text {, while labors and pesticides (cotton) and irrigation costs will be saved. Table C.1 }\end{array}$ \\
\hline
\end{tabular}

Use NI CDC to represent additional cost of enhanced-efficiency fertilizers: in general DCD is applied at rates equivalent to $5 \%$ of N nutrient (w/w), the price of DCD is about $¥ 10000 / \mathrm{t}$.

Zhang et al. (2009)

Zhang et al. (2012b)

Zhang et al.(2009)

$\operatorname{SAIN}(2012)$

Liu et al.(2006)

Zhang(2012)

Yang et al. (2005)

Huo et al. (2011)

Zhang et al. (2012b)

Material and labor inputs for manure composting and disposal are represented by the market price of organic manure fertilizer. More labor inputs needed for large quantity of manure application should be carried out every 3-4 years. Increased seed and pesticide costs are attributed to straw returning.

Increased machine cost is for straw mulching following harvest. Additional $\mathrm{N}$ fertilizers should be added to accelerate fresh straw decay. Large amount of straw is likely to affect seed emerging and encourage weed growth and pest infestation.

Biochar price is represented by the straw pyrolysis product from Sanli NewEnergy Company, Henan, China. More labors are required to apply large amount of biochar. Per tonne biochar price is considered constant thanks to technology improvement. Domestic experts suggest applying biochar every 5 years since single application can provide beneficial effects over several growing seasons in the field.

The investment cost for a anaerobic digester on farm scale is about 3250 Yuan but a subsidy between 800 and 1200 Yuan is provided. The annual benefit of running a digester is estimated to be 500 Yuan. We assume that one anaerobic digester is operational for 15 years and a relative high failure rate of $8 \%$ of new constructed digesters due to immense maintenance and technological short comings

He et al. (2006)

Lv et al. (2010)

Wang et al. (2010)

Jiang et al. (2006)

Liu et al. (2009)

Tian et al. (2011)

Major(2011)

Zhang et al.(2012a)

Pan(2012)

MOA (2007a)

NDRC (2007)

Zhang et al. (2012)

Han et al. (2008) 

respectively (the costs are adjusted to current prices). Due to the low success rate more then one artificial insemination has to be done for one animal. The milk production and body weight will increase by $1 \%$ each year.

A sheep unit that is fed with $1 \mathrm{~g}$ concentrated tea saponins per day shows increased milk production, body weight, and wool/cashmere production of $3 \%, 4 \%$, and $4 \%$, respectively. The feed intake increases by $2 \%$. The costs are at $¥ 125 / \mathrm{Kg}$.*

Waldron et al. (2007)

Zhang and Beckman

(2008)

expert judgement ${ }^{\dagger}$

expert judgement

Musa et al. (2009)

expert judgement input are based number of animals and area for hay making. We assume that the livestock is freely grazing. Thus, no costs a generated by grazing livestock.

questionnaires by the Inner Mongolia Agricultural

University.

Additional management costs of $¥ 2 /$ animal apply for purchasing, transporting, feeding the feed additives.

${ }^{\dagger}$ Since there is a gap in Chinese Scientific literature for the required information, we consulted several Chinese experts on their judgment of impact on yields and costs. The results presented here are the mean of all assumptions. 
Table D.2 Agricultural inputs in 2010 and anticipated future change (taking rice as an example)

\begin{tabular}{|c|c|c|c|c|}
\hline Item & Unit & 2010 & $\begin{array}{c}\text { Annual } \\
\text { growth rate } \\
2000-2010^{*}\end{array}$ & $\begin{array}{c}\text { Assumed } \\
\text { annual growth } \\
\text { rate } 2010-2020\end{array}$ \\
\hline Direct material and service cost/0.067ha & yuan & 303.93 & $7 \%$ & $4 \%$ \\
\hline 1.seed cost & yuan & 39.74 & $8 \%$ & $4 \%$ \\
\hline 2.fertilizer cost & yuan & 110.94 & $7 \%$ & $3 \%$ \\
\hline 3.organic manure cost & yuan & 9.65 & $1 \%$ & $0 \%$ \\
\hline 4.pesticide cost & yuan & 22.39 & $11 \%$ & $5 \%$ \\
\hline 5.agri. film cost & yuan & 2.34 & $3 \%$ & $1 \%$ \\
\hline 6.renting and operation cost & yuan & 113.19 & $12 \%$ & $6 \%$ \\
\hline $\begin{array}{l}\text { machine renting and } \\
\text { operation }\end{array}$ & yuan & 84.94 & $14 \%$ & $7 \%$ \\
\hline irrigation and drainage & yuan & 19.08 & $2 \%$ & $1 \%$ \\
\hline water cost & yuan & 6.69 & $0.4 \%$ & $0.2 \%$ \\
\hline animal power cost & yuan & 9.17 & $-3 \%$ & $-1 \%$ \\
\hline 7.fuel and power cost & yuan & 0.68 & $22 \%$ & $5 \%$ \\
\hline 8.technical service cost & yuan & 0.02 & $-26 \%$ & $-13 \%$ \\
\hline 9.tool and material cost & yuan & 3.40 & $34 \%$ & $17 \%$ \\
\hline 10.maintenance and repair cost & yuan & 1.57 & $-0.7 \%$ & $-0.4 \%$ \\
\hline 11.other direct cost & yuan & 0.01 & $-43 \%$ & $-22 \%$ \\
\hline Human cost/0.067ha & yuan & 226.90 & $6 \%$ & $3 \%$ \\
\hline 1.equivalent family labor cost & yuan & 206.27 & $6 \%$ & $3 \%$ \\
\hline human input days & day & 6.59 & $-6 \%$ & $-3 \%$ \\
\hline labor wage & yuan/day & 31.30 & $12 \%$ & $6 \%$ \\
\hline 2.hiring labor cost & yuan & 20.63 & $8 \%$ & $4 \%$ \\
\hline human input days & day & 0.34 & $-4 \%$ & $-2 \%$ \\
\hline labor wage & yuan/day & 60.67 & $12 \%$ & $6 \%$ \\
\hline Fertilizer price & yuan/kg & 4.83 & $7 \%$ & $4 \%$ \\
\hline $\mathrm{N}$ fertilizer price & yuan/kg & 3.96 & $6 \%$ & $3 \%$ \\
\hline
\end{tabular}

* Growth rate of 2005-2010 was used when the rate for 2000-2010 was not available. 
Table D.3 Measure adoption rates under baseline and abatement scenarios

\begin{tabular}{llll}
\hline Measure & Historical or current adoption & Baseline adoption in 2020 & Maximum feasible adoption in 2020
\end{tabular}

No.

$\mathrm{C} 1$

$\mathrm{C} 2$

C3

C4

C5 Limited

Areas under F, F-D-F, F-D-F-M regimes were $16 \%, 77 \%, 7 \%$ in $1980 \mathrm{~s}$ and $12 \%, 76 \%, 12 \%$ in 1990 s.

C8

C9 Limited

4.30 Mha $(7.6 \%$ of wheat and maize areas) in 2010

28.5Mha(about 18 Mha of wheat and maize areas, $60 \%$ of mechanized harvest areas receive straw returning)

L1 $33 \%$ of total $120 \mathrm{M}$ possible farm-scale anaerobic digesters
Apply to $39 \%$ rice, $44 \%$ wheat, $55 \%$ maize, $100 \%$ greenhouse veg., 50\% See Table S7 measure C1 openfield veg. and $70 \%$ fruit fields.

Apply to $100 \%$ wheat and maize cropping areas.

See Table C.1 measure C2

Areas under F, F-D-F, F-D-F-M Areas under F, F-D-F, F-D-F-M Zou et al. (2009)

regimes are $8 \%, 76 \%, 16 \%$.

regimes are $8 \%, 0 \%, 92 \%$

Zhang et al.(2011)

$50 \%$ of cotton, greenhouse and Apply to $100 \%$ cotton, greenhouse openfield vegetable and fruit fields. and openfield vegetable and fruit fields.

See Table C. 1 measure C4.

National Agricultural Water-Saving Outline (2012-2020)

Apply to 50\% rice, wheat and maize cropping areas, $30 \%$ other upland crops (excluding beans), and $30 \%$ of vegetable and fruit areas.

$30 \%$ of crops receive reasonable $80 \%$ of crops (except greenhouse supply of organic manure.

veg.) receive reasonable supply of organic manure.

20 Mha $(34.8 \%$ of wheat and maize areas)

23 Mha $(40 \%$ of wheat and maize areas)

National Agriculture Mechanization Extension Plan (2011-2015)

22.5 Mha of wheat and maize areas(assuming $60 \%$ of mechanized harvest areas receive straw returning ${ }^{\dagger}$

30.1Mha of wheat and maize areas(assuming $80 \%$ of mechanized harvest areas receive straw returning)

Limited

Apply to $10 \%$ of rice, wheat and

National Agriculture Mechanization Extension Plan (2011-2015). Implementation Plan on the Comprehensive Use of Crop Straw during the 12th Five-year Plan Period
$66 \%$ of total possible farm-scale anaerobic digesters maize cropping areas.

$33 \%$ of total possible farm-scale NDRC (2007)

anaerobic digesters 

under grazing ban, suspended grazing, or rotational grazing.

Limited

In 2010, 60\% of Chinese grassland is under grazing ban, suspended grazing, or rotational grazing. most common for beef and cow bu practically non-existent for goat farm

\section{Very limited}

Increasing adoption rate

\section{Limited}

Limited
$20 \%$ of beef and dairy cattle, $30 \%$ of

sheep, $60 \%$ for goat

\section{$10 \%$ of livestock since tea saponins Expert opinion} are not sufficient available

$50 \%$ of livestock

$70 \%$ of livestock

$33 \%$ of grazing grassland

$33 \%$ of grazing grassland

Limited
Wang et al. (2008)

Beijing Shennong Agricultural Consultancy. (2013) Research Report on Feeding Probitics Industry in China

\section{Expert opinion}

18th formal announcement of the strategic objectives of the sustainable development of Chinese grassland (in Chinese)

Ministry of Environmental Protection of People's Republic of China (2005 - 2011) Report on the State of the Environment of China (in Chinese)

Brown et al. (2008)

18th formal announcement of the strategic objectives of the sustainable development of Chinese grassland (in Chinese)

Ministry of Environmental Protection of People's Republic of China (2005 - 2011) Report on the State of the Environment of China (in Chinese)

\footnotetext{
*According to the National Agricultural Water-Saving Outline, high-efficiency irrigations shall be installed on 22.5 Mha croplands (20 Mha new areas). We estimate that approximately $30 \%$ of cash crops shall benefit from this project.

${ }^{\dagger}$ Straw returning rate is highly dependent on crop harvesting mechanization levels, which were $64.5 \%$ for rice, $86 \%$ for wheat and $25.8 \%$ for maize in 2010 , and are planned to reach $80 \%$ for rice and $45 \%$ for maize in 2015 .
} 


\section{References}

AKIYAMA, H., YAN, X.Y., YAGI, K., 2010. Evaluation of effectiveness of enhanced-efficiency fertilizers as mitigation options for $\mathrm{N} 2 \mathrm{O}$ and $\mathrm{NO}$ emissions from agricultural soils: meta-analysis. Global Change Biology 16, 1837-1846.

Bai, X., Xia, Z.W., Guo, Y.L., 2012. Effects of nitrification inhibitors on N2O emission from different upland agricultural soils. Chinese Journal of Ecology, 31, 2319-2329.

Brown, C.G., 2008. Sustainable development in Western China: managing people, livestock and grasslands in pastoral areas. Edward Elgar Publishing, Cheltenham, UK.

Chadwick, D., Qing, C., Tong, Y.A., Shen, Q.R., Yu, G.H., 2013. A review of Manure nutrient Use in China to develop a more rational approach to utilising organic manures and anaerobic digestaters as part of the development of integrated nutrient management planning with inorganic fertilizers (MUC). Forthcoming paper.

Gao, L,W, Ma, L, Zhang, W.F., Wang, F.H., Ma, W.Q., Zhang, F.S., (2009 Estimation of nutrient resource quantity of crop straw and its utilization situation in China. Transactions of the Chinese Society of Agricultural Engineering 25, 173-179. (in Chinese with English abstract)

Gao, B., Ju, X.T., Zhang, Q., Christie, P., Zhang, F.S., 2011. New estimates of direct N2O emissions from Chinese croplands from 1980 to 2007 using localized emission factors. Biogeosciences Discussions 8, 6971-7006.

Ge, X.Y., 2009. Assessment of NPK Fertilizer Consumption and Demand in Vegetable System in China. Master Thesis, China Agricultural University, Beijing, 155pp. (in Chinese with English abstract).

He, J., Li, H.W., Gao, H.W., 2006. Subsoiling effect and economic benefit under conservation tillage mode in Northern China. Transactions of the Chinese Society of Agricultural Engineering, 10, 62-67.(in Chinese with English abstract)

HUANG, Y., TANG, Y., 2010. An estimate of greenhouse gas (N2O and CO2) mitigation potential under various scenarios of nitrogen use efficiency in Chinese croplands. Global Change Biology $16,2958-2970$.

Huo,Y., Zhang, M., Wang, H., 2011. Real Example Analysis of Cost Differential and Influencing Factors of Xinjiang Cotton under Drip Irrigation. Water Saving Irrigation, 8, 61-63. (in Chinese with English abstract)

Jiang, Y.H., Guo, S.Z., 2006. Benefits analysis and economic consideration of maize straw returning in north China. China Agricultural Technology Extension, 1, 43-44(2006). (in Chinese)

Jiao, X.Y., Wang, L.G., Zhang, D.L., Zhang, J.S., Dong, E.W., 2010. Present situation of fertilizer application, its problems and suggestions concerning vegetable production under conditions of solar-greenhouse. J. Shanxi Agric. Sci., 38, 37-41. (in Chinese with English abstract).

Liu, F.P., Xie, H.W., 2006. Comparative Analysis of Water-saving Benefit among Different Irrigation Modes of Rice. Acta Agriculturae Jiangxi, 18, 10-13. (in Chinese)

Liu, S.P., Chen, H.Q., Chen, W.L., Dai, Q.G., Huo, Z.Y., Xu, K., Zhang, H.C., 2009. Comprehensive evaluation of tillage and straw returning on yearly productivity. Transactions of the Chinese Society of Agricultural Engineering, 4, 82-85. (in Chinese with English abstract) 
Liu, C., Wang, K., Zheng, X., 2013. Effects of nitrification inhibitors (DCD and DMPP) on nitrous oxide emission, crop yield and nitrogen uptake in a wheat-maize cropping system.

Biogeosciences 10, 2427-2437.

Lu. S.C., Chen, Q., Zhang, F.S., 2008. Analysis of nitrogen input and soil nitrogen load in orchards of Hebei province. Plant Nutr. Fertil. Sci. 14, 858-865. (in Chinese with English abstract)

Lv, J., Ma, L., Han, X.Y., 2010. Analysis of differences on economic benefits between conservation tillage and conventional tillage- based on Fuxin experiment research and household survey. Agricultural Economy , 8, 27-28. (in Chinese)

Major, J., 2010. Guidelines on Practical Aspects of Biochar Application to Field Soil in Various Soil Management Systems. International Biochar Initiative.

Ministry of Agriculture (MOA) of the P.R.C., 2001-2012a. China Livestock Yearbook. China Agricultural Press, Beijing.

Ministry of Agriculture (MOA) of the P.R.C., 2001-2012b. China Rural Statistical Yearbook. China Agricultural Press, Beijing.

Ministry of Agriculture (MOA) of the P.R.C., 2007. National rural biogas digesters construction plan (2006-2010), Beijing. (in Chinese).

Ministry of Agriculture (MOA) of the P.R.C., 2011. National Agriculture Mechanization Extension Plan (2011-2015), Beijing.

Ministry of Environmental Protection of People's Republic of China (MOEP), 2005 - 2011. Report on the State of the Environment of China. China Environment Science Press, Beijing. (in Chinese)

Musa, H.H., Wu, S.L., Zhu, C.H., Seri, H.I., Zhu, G.Q., 2009. The potential benefits of probiotics in animal production and health. Journal of Animal and Veterinary Advances, 8, 313-321.

National Development and Reform Committee (NDRC) of the P.R.C., 2007. Medium and Long-term development plan for renewable energy, Beijing.

National Coordination Committee on Climate Change (NCCC), 2012. Second National Communication on Climate Change of the People's Republic of China.

National Development and Reform Committee (NDRC) of the P.R.C., 1998-2012. China Agricultural Products Cost-Benefit Yearbook. China Statistics Press, Beijing.

Nayak, D., Cheng, K., Wang, W., Moran, D., Yan, X.Y., Guo, M., Cardenas, L., Pan, G.X., Smith, P., 2013. Technical Options to reduce greenhouse gas emission from rice agriculture in China (In submission )

NCCC, 2004. The People's Republic of China-Initial National Communication on Climate Change. China Planning Press, Beijing.

Pan, G.X., 2012. Black for Green: A perspective on Biochar and Green Agriculture of China: A Meta-analysis of Field Studies. Outreach conference of the UK-China Sustainable Agriculture Innovation Network (SAIN), Beijing.

SAIN, 2012. Policies and technologies to overcome excessive and inefficient use of nitrogen fertilizer: delivering multiple benefits. SAIN Policy Brief No. 5.

SAIN, 2012b. Improving manure nutrient management towards sustainable intensification in China. SAIN Policy Brief No.6 
State Council of China, 2012. National Agricultural Water-Saving Outline (2012-2020). http://www.gov.cn/zwgk/2012-12/15/content_2291002.htm

Sun, W.J., Huang, Y., 2012. Synthetic fertilizer management for China's cereal crops has reduced $\mathrm{N}_{2} \mathrm{O}$ emissions since the early 2000s. Environmental Pollution, 160, 24-27.

Sun, M.Y., Zhu, D.L., Zhang, L., 2013. Factors Affecting Farmers' Satisfaction towards Greenhouse Drip Irrigation Technology. Water Saving Irrigation, 4, 55-58(2013). ( in Chinese with English abstract)

Tian, Q., Du, X., Zhang, H.M., Zhou, J.H., 2011. The Effect of Agricultural Machinery Purchase Subsidies on Mechanized Crop Residue Recycling. Journal of Anhui Agricultural Sciences, 22, 13821-13823. (in Chinese with English abstract)

Waldron, S.A., Brown, C.G., Longworth, J.W. and Zhang, C.G., 2007. China's Livestock Revolution: Agribusiness and Policy Developments in the Sheep Meat Industry. CAB International, Wallingford.

Wang, Y.B., Li, J.R., Lin, J., 2008. Probiotics in aquaculture: challenges and outlook. Aquaculture, 281, $1-4$.

Wang, J.Y., Liu, Q.H., Liu, J.L, (2010. Analysis on the characteristic and cause of orchard soil acidification in the area of Shandong peninsula. Chin. Agric. Sci. Bull,. 26,164-169. (in Chinese with English abstract)

Wang, J.X., Zhang, L.J., 2010. Impacts of Conservation Tillage on Agriculture: Empirical Research in the Yellow River Basin. Management Review, 6, 77-84. (in Chinese with English abstract)

Yang, J.L., Wu, E.R., Wang, X.K., 2005. Comparison and analysis of inputs for cotton drip irrigation and furrow irrigation. Xinjiang State Farms Economy, 10, 68-71. (in Chinese)

Zhang, J., Beckman, C., 2008. People's Republic of China: Agricultural Situation: Livestock and Products 2008. United States Department of Agriculture Foreign Agricultural Service, Beijing.

Zhang, F.S., Chen, X.P., Chen, Q., 2009. Fertilization guidelines for major crops in China. China' Agriculture University Press, Beijing. (in Chinese)

Zhang, W., Yu, Y., Huang, Y., Li, T., Wang, P., 2011. Modeling methane emissions from irrigated rice cultivation in China from 1960 to 2050. Global Change Biology 17, 3511-3523.

Zhang, Z.X., 2012. Experiment for Water-Saving and Greenhouse Effect of Irrigation Mode in Cold Rice Area. PhD dissertation, Northeast Agricultural University, Xi'an. (in Chinese with English abstract)

Zhang, A.F., Liu, Y., Pan, G.X, Hussain, Q., Li, L., Zheng, J., Zhang, X., 2012a. Effect of biochar amendment on maize yield and greenhouse gas emissions from a soil organic carbon poor calcareous loamy soil from Central China Plain. Plant and Soil 351, 263-275.

Zhang, F.S, Cui, Z.L., Chen, X.P., Ju, X.T., Shen, J., Chen, Q., Liu, X., Zhang, W.F., Mi, G., Fan, M., Jiang, R., 2012b. Chapter one - Integrated Nutrient Management for Food Security and Environmental Quality in China, in: Sparks, D.L. (Ed.), Academic Press, pp. 1-40.

Zhang, T., Bu, M.D., Geng, W., 2012c. Pollution status and biogas producing potential of livestock and poultry excrements in China. Chinese Journal of Applied Ecology, 23, 2015-2025. (in Chinese)

Zhang, W.F., Dou, Z.X., He, P., Ju, X.T., Powlson, D., Chadwick, D., Norse, D., Lu, Y.L., Zhang, Y., Wu, L., Chen, X.P., Cassman, K.G., Zhang, F.S., 2013. New technologies reduce greenhouse gas 
emissions from nitrogenous fertilizer in China. Proceedings of the National Academy of Sciences $110,8375-8380$.

ZOU, J., HUANG, Y., QIN, Y.M, LIU, S.W, SHEN, Q.R, PAN, G.X, LU, Y.Y, LIU, Q.H., 2009. Changes in fertilizer-induced direct $\mathrm{N} 2 \mathrm{O}$ emissions from paddy fields during rice-growing season in China between 1950s and 1990s. Global Change Biology 15, 229-242.

Zou, X.X., Li, Y.E., Cremades, R., Gao, Q.Z., Wan, Y.F., Qin, X.B., 2013. Cost-Effectiveness Analysis and Potential of Water-Saving Irrigation based Climate Change Response: a Case Study of China. Agricultural Water Management forthcoming paper. 



\section{Working Paper Series}

$n^{\circ} 2013-10$

$n^{\circ}$ 2013-10

\section{$n^{\circ}$ 2013-09}

Greenhouse gas mitigation in Chinese agriculture: distinguishing technical and economic potentials

By Wen Wang, Frank Koslowski, Dali Rani Nayak, Pete Smith, Eli Saetnan, Xiaotang Ju, Liping Guo, Guodong Han, Christian de Perthuis, Erda Lin and Dominic Moran

Carbon and energy prices under uncertainty: A theoretical analysis of fuel switching with non-equally efficient power plants

By Vincent Bertrand

A stochastic generalized Nash-Cournot model for the northwestern European natural gas markets: The S-GaMMES model By Ibrahim Abada and Pierre-André Jouvet

\section{Governance of $\mathrm{CO}_{2}$ markets: Lessons from the EU ETS}

By Christian de Perthuis and Raphael Trotignon

Switching to biomass co-firing in European coal power plants: Estimating the biomass and $\mathrm{CO}_{2}$ breakeven prices

By Vincent Bertrand

EU ETS Phase 3 benchmarks: Implications and potential flaws

By Stephen Lecourt

Modeling of Emission Allowance Markets: A Literature Review By Vincent Bertrand

An empirical analysis of the cumulative nature of deforestation By Julien Wolfersberger, Serge Garcia and Philippe Delacote

Contact us :

Chaire Economie du Climat - Palais Brongniart (4e étage)

28 Place de la Bourse, 75002 Paris

Tel : +33 (0)173019331

Email : contact@chaireeconomieduclimat.org 